This is a pre-copyedited, author-produced version of an article accepted for publication in BioScience following peer review. The version of record [Wohl, E, Kramer, N., Ruiz-Villanueva, V., Scott, D., Comiti, F., Gurnell, A., Piégay, H., Lininger, K., Jaeger, K., Walters, D., Fausch, K. 2019. The Natural Wood Regime, Bioscience, 69] is available online at https://academic.oup.com/bioscience/articlelookup/doi/10.1093/biosci/biz013

\title{
The Natural Wood Regime in Rivers
}

\author{
Ellen Wohl, Natalie Kramer, Virginia Ruiz-Villanueva, Daniel Scott, Francesco Comiti, Angela \\ Gurnell, Herve Piégay, Katherine Lininger, Kristin Jaeger, David Walters, Kurt Fausch
}

\begin{abstract}
The natural wood regime forms the third leg of a tripod of physical processes that supports river science and management, along with the natural flow and sediment regimes. The wood regime consists of wood recruitment, transport, and storage in river corridors. Each of these components can be characterized in terms of magnitude, frequency, rate, timing, duration, and mode. We distinguish the natural wood regime, which occurs where human activities do not significantly alter the wood regime, and a target wood regime when management emphasizes wood recruitment, transport, and storage that balance desired geomorphic and ecological characteristics with mitigation of wood-related hazards. Wood regimes vary across space and through time, but can be inferred and quantified via direct measurements, reference sites, historical information, and numerical modeling. Classifying wood regimes with respect to wood process domains and quantifying the wood budget are valuable tools for assessing and managing rivers.
\end{abstract}

Classic geomorphic conceptualizations of rivers focus exclusively on interactions between water and sediment (e.g., Lane's balance, Lane 1955). Although water has sometimes been accorded dominance as a driving force on river process and form, the importance of sediment supply is also widely recognized. Boundary resistance to erosion is a fundamental influence on river process and form, and in this context the role of riparian vegetation is now well acknowledged, especially for low energy rivers (Gurnell et al. 2012, Gurnell 2014, Corenblit et al. 2015). Analogously, the effect of upland vegetation on sediment inputs to rivers is traditionally recognized for its role in limiting surface erosion and hillslope mass movement (e.g., Schumm 1968). The fundamental influence of vegetation as a geomorphic agent and as a source of wood to rivers is much less widely recognized in foundational literature, likely because of the long history of wood removal from river corridors by humans (Triska 1984, Montgomery et al. 2003, Wohl 2014). This last point is worth emphasizing: historical descriptions of forested regions throughout the temperate latitudes indicate that orders of magnitude more wood were present in most forested river corridors prior to widespread 
deforestation and wood removal from river corridors for navigation and flood mitigation (Sedell and Froggatt 1984).

In the context of this increasing knowledge of flow, sediment, and vegetation interactions, long-held arguments for the importance of a natural flow regime are based on the understanding that the geomorphic and ecological integrity of a river depend on its natural dynamic character. The original conceptualization of this dynamic character emphasized the importance of variations in fluxes of water through time (Poff et al. 1997). The conceptualization of a natural sediment regime broadened the consideration of a river's dynamic character to reflect the importance of water and sediment interactions and sediment fluxes (Wohl et al. 2015). These two conceptual models recognize that centuries of human activities have created diverse changes in rivers, including alteration of natural flow and sediment regimes. These alterations have resulted in extensive ecological degradation and loss of biodiversity. Human activities on land and along rivers have also extensively changed and reduced important functions that include wood characteristics in river corridors. Alterations in the wood regime, however, are rarely recognized compared to the attention given to altered water and sediment regimes. Here, we argue that understanding the natural wood regime forms the third leg of a tripod supporting the physical processes underlying river science and management, along with the natural flow and sediment regimes. We define the wood regime in terms of the magnitude, frequency, rate, timing, duration, and mode of wood recruitment, transport, and storage.

Large wood traditionally refers to downed, dead pieces greater than $10 \mathrm{~cm}$ in diameter and $1 \mathrm{~m}$ in length. Aggregates of smaller wood pieces (Culp et al. 1996, Galia et al. 2018) and living wood within the river corridor (Gurnell and Petts 2002, Gurnell et al. 2005, Opperman et al. 2008) also create important physical and ecological effects in river corridors. As a fundamental component of trees, wood contributes to the overall role of vegetation in driving forested river corridor form and function (Maser and Sedell 1994). Here, the river corridor includes fluvially influenced portions of a valley floor, such as the active channel(s), the floodplain and low terraces, the riparian zone, and the hyporheic zone. Explicit focus on river corridors, rather than channels, recognizes the vital importance of interactions between different portions of the valley bottom in the context of fluxes of water, sediment, and wood at network- to reach-scales (Hynes 1975). We consider a river corridor's wood regime to include all sizes and types of wood.

A rapidly growing literature documents the beneficial effects of wood on the geomorphology and ecology of rivers (Figure 1, Supplemental Table 1). Wood affects channel and floodplain ecological function via controls on riparian plant community development and structure, aquatic habitat, dynamics of particulate organic matter storage and processing, and the structure and production of biological communities. Wood influences longitudinal, lateral, and vertical fluxes of water, solutes, and mineral sediment - connectivity - within river corridors. Wood also changes channel and floodplain form both when the wood pieces are mobile and when they are stored. Failure to adequately consider these effects distorts our understanding of river process and form. On the other hand, wood transport can create flood hazards associated with wood accumulation at structures such as bridges, where jams can create substantial bed scour and flooding. Because of hazards and other constraints, a natural 
wood regime may no longer be feasible in rivers with high flood risk. In these circumstances, a more pragmatic target wood regime should be identified and pursued to create at least some of the positive effects of wood in river ecosystems.

Analogous to natural and altered water and sediment regimes, we draw a distinction in this paper between the natural wood regime and a target wood regime. A natural wood regime occurs where past and present human activities do not significantly alter the components of the wood regime. In many historically forested river corridors, however, human alterations of the mechanisms and magnitudes of the wood regime have been so sustained and intensive that it is no longer feasible to infer or restore a fully natural wood regime. Management can then be directed toward a target wood regime in which wood recruitment, transport, and storage balance desired geomorphic and ecological characteristics within the current landscape constraints and with mitigation of wood-related hazards. Our objectives in this paper are to (i) define and characterize the wood regime and (ii) provide perspectives on how to characterize and manage for natural and target wood regimes to increase geomorphic and ecological integrity of river corridors.

\section{The Wood Regime}

Similar to flow and sediment regimes, a wood regime is temporally focused, with fluxes and storage of wood as the characteristics of interest. A wood regime may be most intuitively analogous to a sediment regime because it exhibits many parallels to mineral sediment (Gurnell 2007). Wood, like sediment, can be stored in a river corridor for long periods and thus time interval is relevant to understanding the wood regime. Wood enters a river corridor and is moved by high flows and, in some steep mountain streams, by debris flows. The movement of wood, including recruitment to and transport along the river corridor, is commonly intermittent, with relatively long periods of locational stability between episodes of movement (Kramer and Wohl 2017). Wood characteristics continue to change both at rest and in transport, via processes of decay, abrasion, and breakage that are analogous to weathering, abrasion, and breakage of stationary mineral sediment, although rates of change in wood are likely to be faster than changes in sediment. Like sediment coming from uplands, the amount, piece size, morphology, and rate of change of wood can reflect processes and controls external to the river corridor, such as forest disturbance regime, forest composition, and forest successional processes. Finally, both movement and storage of wood influence river process and form and in turn riparian and aquatic habitat. The balance between wood recruitment, transport, and storage both reflects river corridor geometry, as geometry creates trapping sites for wood, and influences geometry, as stored wood influences processes such as sediment deposition and the formation of steps and pools, bars, and secondary channels (Keller et al. 1995, Wohl et al. 2018b).

The analogies between sediment and large wood regimes should not overshadow the importance of recognizing large wood as distinctive and equal in importance to water and sediment as a component of river geomorphic process and form. A natural wood regime commonly shows substantial variation through time (Figure 2) and across a river network (Figure 3) that may not parallel those of water and sediment. The natural wood regime for a river segment or river network reflects the distinctive characteristics of that ecoregion, 
including the tree species present and available for recruitment and the associated size and physical complexity (e.g., branching) of recruited wood, as well as the rates of decay and breakage that influence wood transport and storage. The natural wood regime also reflects the distinctive physical characteristics of a river network or portion of a network, including the disturbance regime (e.g., blight and insect infestations, tropical cyclones, debris flows, landslides, ice storms, snow avalanches, wildfires) that influences wood recruitment; the natural flow and sediment regimes that govern wood transport and modification while in storage (e.g., via wetting and drying or abrasion); and the geometry of the river corridor that governs the presence and connectivity of portions of the valley bottom outside of the active channel, from which wood can be recruited and in which wood can be stored.

Sediment and wood regimes have previously been conceptualized in the form of a budget in which storage results from the difference between inputs and outputs within a defined area over a specified time interval. Wood budgets have been developed for application to timespans ranging from centuries (Benda and Sias 2003) to a single flood (Lucía et al. 2015, Comiti et al. 2016) (Supplemental Text 1). Although we recognize the usefulness of a budget as a means of quantifying the wood regime, here we use the framework of a wood regime to emphasize temporal fluctuations in wood dynamics.

The natural flow regime focuses on water flux. Poff et al. (1997) used systematic records of stream flow to quantify characteristics of magnitude, frequency, duration, timing, and rate of change in water discharge. Although time-series data are particularly useful in characterizing natural flow regimes, analogous data are much more limited for sediment regimes (Wohl et al. 2015) and few exist for wood regimes. In addition, the details of how wood is recruited to and stored within a river corridor strongly influence the wood regime. Given this, we propose that six components within each of the processes of wood recruitment, transport, and storage are required to describe the wood regime at a site (Table 1):

- Magnitude refers to the relative or absolute volume or mass of wood recruited, transported, or stored.

- Frequency refers to how often wood is recruited, mobilized and transported, or deposited in storage.

- Duration refers to the length of time over which recruitment events occur, or wood is transported or stored.

- Timing refers to when wood is recruited, transported, and stored, with respect to either seasonal patterns or components of the flow regime (e.g., recruitment during the rising limb and flood peak, deposition of wood during the recessional limb).

- Rate refers to the flux (mass or volume per unit of time) at which wood is recruited or transported; or the flux of wood mass lost by decay, breakage, and abrasion during storage.

- Mode refers to the process by which wood is recruited and transported and the location and form (e.g., jams or dispersed pieces) of wood storage within the river corridor.

The six aspects of the wood regime outlined above can have varying degrees of importance relative to one another depending on environmental conditions and reasons for 
which this framework is being used. For example, comparing wood storage duration with the rate of wood mass loss by decay, breakage, and abrasion can indicate how changes in the frequency of wood transporting flows (e.g., by dams or diversions) might affect wood stored downstream. Alternatively, comparing the timing of recruitment events to the timing of wood transporting flows can yield insights into the mechanisms of wood storage. Although the wood regime should always be considered holistically, because many aspects are interrelated, some aspects of the wood regime or interactions between aspects may be disproportionately important for a given management or research scenario.

In the following sections, we discuss sources of spatial and temporal variability in each of the components of a wood regime and review methods used to quantify each component.

\section{Recruitment}

Spatial variations in recruitment reflect variations in forest characteristics and processes that move wood into river corridors. Forests are characterized by primary productivity and associated forest stand density, tree diameter and height, species (which influences wood density, piece form or branching, decay rate, and re-sprouting of deposited pieces), all of which differ substantially among bioclimatic regions and within a river catchment if the catchment spans sufficient elevational or latitudinal range (e.g., Wohl 2011). Recruitment mechanisms also vary spatially as connectivity between different portions of the river corridor and hillslopes, as well as wood transport and forest disturbance, vary downstream. Individual tree mortality, mass movements, and avalanches may be particularly important sources of lateral wood inputs in low-order, confined channels (Keller et al. 1995, May and Gresswell 2003), for example, whereas bank erosion is likely to become progressively more important as a source of lateral wood recruitment in partly-confined and unconfined river segments (Lassettre et al. 2008, Lucía et al. 2015, Ruiz-Villanueva et al. 2018). Human alterations may also influence the spatial extent and age of forests, as well as the dominance of different recruitment processes, heterogeneously throughout watersheds.

Temporal variation in wood recruitment reflects the varying importance of different mechanisms and magnitudes of recruitment. Over time intervals of decades to centuries, wood recruitment may be dominated by episodic recruitment of forest patches associated with severe storms (Phillips and Park 2009) or hillslope instability (May and Gresswell 2003), for example, but recruitment of individual trees via both continual and episodic bank erosion appears to be particularly important at shorter time intervals along downstream portions of many channels (e.g., Piégay et al. 2017). A wood budget provides a useful framework for explicitly identifying spatial and temporal variation in diverse forms of wood recruitment (e.g., Benda and Sias 2003, Wohl 2011).

Wood recruitment to a river corridor can be quantified using at least two approaches. Direct measurements commonly cover only short periods such as a single large storm or flood (e.g., Comiti et al. 2016) or at most a few decades (Boivin et al. 2015). Numerical models typically focus on either forest dynamics over decades to centuries and the resulting magnitude and frequency of wood recruitment (Gregory et al., 2003) or on the potential for recruitment during a single storm or flood in relation to factors such as volume of standing wood and processes that recruit that wood to the river corridor (e.g., landslides: Mazzorana et al. 2011). 


\section{Transport}

The portion of the wood regime that characterizes transport is the most similar to the characterization of the natural flow regime. Although the characteristics of flow are the firstorder controls on wood transport, spatial and temporal variation in channel and floodplain geometry, sediment inputs and mobility, wood piece size, and wood storage (e.g., dispersed pieces vs jams) all influence wood transport. Distinctly different conditions may characterize wood entrainment, or the initiation of motion, and wood transport. The relative importance of downstream transport or deposition on the channel margins or floodplain varies with factors such as channel size (Gurnell 2003), channel-floodplain connectivity (Wohl et al. 2018a), local flow width and depth, and flow regime (Kramer and Wohl 2017). Temporal factors such as stage of the flood hydrograph (MacVicar and Piégay 2012, Kramer and Wohl 2017) and recent history of high flows also influence mobilization and transport of wood. The first significant flood after recruitment, for example, can play a disproportionately large role in wood dispersal relative to subsequent flows (Millington and Sear 2007). Wood transport magnitude-frequency relationships could be useful to understand wood regimes, but appropriate data series of wood flux in relation to stream discharge are just starting to be developed for a few rivers (Kramer and Wohl 2017).

Direct measurements of wood transport and input/output fluxes are rare but can be undertaken using field measurements at a station (Turowski et al. 2013), time-lapse photography of a channel (e.g., MacVicar and Piégay 2012, Benacchio et al. 2017), or archived airborne imagery at coarser, but more extensive scales and longer periods (e.g., Senter et al. 2017). Numerical models are also used to examine transport over diverse time scales and hydraulic conditions (e.g., Lancaster et al. 2001, Mazzorana et al. 2011, Ruiz-Villanueva et al. 2014).

\section{Storage}

Magnitude, duration, and mode of wood storage have received more attention than any component of wood recruitment and transport. Magnitude of wood storage is commonly quantified as volume of wood per spatial unit (e.g., $\mathrm{m}^{3}$ wood per hectare of surface or per unit length of channel) and is referred to as wood load (Van der Nat 2003). Compilations of published wood loads indicate enormous variability within and between river networks, with ranges of 10 to $\sim 50 \mathrm{~m}^{3} /$ ha for unmanaged floodplains (Lininger et al. 2017) and 0 to $\sim 5000$ $\mathrm{m}^{3} /$ ha for unmanaged channels (Ruiz-Villanueva et al. 2016, Wohl et al. 2017).

Most studies focus on wood load in relation to drainage area or bankfull channel width, both within a river network and between networks (e.g., Gurnell 2003, Fox and Bolton 2007, Ruiz-Villanueva et al. 2016, Wohl et al. 2017). Although significant trends exist between channel wood load and predictor variables such as drainage area or bankfull width within a region, relationships are highly variable and break down when applied to data from multiple regions (Gurnell 2013, Wohl et al. 2017). In addition, insufficient data on floodplain wood loads exist to allow analyses of the entire river corridor (Lininger et al. 2017).

Insight into past wood loads under natural wood regimes can be obtained from modeling, reference sites, and historical records. Numerical (e.g., Lancaster et al. 2001, Mazzorana et al. 2011, Ruiz-Villanueva et al. 2014) and stochastic (e.g., Eaton et al. 2012) 
models have been developed to quantitatively estimate wood deposition and storage over diverse time scales.

Reference sites are otherwise analogous sites in which the multiple factors that influence the wood regime have not been substantially altered by human activities. Because of the significant temporal and spatial variability in processes influencing the wood regime, inferences from sites disturbed minimally by humans probably provide at best a first-order approximation and are most useful when based on regional, rather than site-specific averages (e.g., Richmond and Fausch 1995, Fox and Bolton 2007).

Historical information can provide particularly useful qualitative (or, rarely, quantitative) insight into magnitude of river corridor wood storage in regions such as North America, Australia, and New Zealand prior to European settlement. Probably the most striking example is the Great Raft on the Red River in Louisiana, USA (Triska 1984). More commonly, historical accounts provide qualitative insight into the effects of loss of stored wood on flooding, navigation, and river corridor processes (e.g., Sedell and Froggatt 1984, Harmon et al. 1986, Wohl 2014) (Supplemental Text 2).

Duration of wood storage within the active channel or floodplain can vary enormously, from less than one year to $>10,000$ years (Nanson et al. 1995, Wohl 2013, 2017). Factors controlling duration include wood piece size relative to channel size; position of wood within the river corridor and accumulation in jams; tree species; climate; degree of saturation of wood; and flow and sediment regimes (Le Lay et al. 2013, Ruiz-Villanueva et al. 2016). Because of the potential for trapping among the trunks of living trees (Wohl et al. 2018a) or burial during overbank or lateral accretion (Guyette et al. 2008, Collins et al. 2012), floodplain wood can have longer storage times than wood within the channel. Rates of decay in relation to tree species, size and stability of wood piece, and climatic conditions have also received limited attention (Harmon et al. 1986), but clearly vary significantly between regions (Wohl 2017), varying from 50 to 100 years for complete decay in dry climates to 10 to 100 years in humid temperate climates and less than 10 years in the humid tropics.

Mode of wood storage has been examined as dispersed versus concentrated (logjams) wood pieces (e.g., Kraft et al. 2011) over varying lengths of channel. Spatial variations in logjams occur at the network-scale, such as in situ jams in headwater channels versus transport jams in larger channels (Abbe and Montgomery 2003), as well as at the reach scale, with preferential formation of jams in portions of the channel such as bars and islands (e.g., Piégay 1993). Similarly, floodplain wood can be concentrated in jams across the floodplain or predominantly along the floodplain margins (Wohl et al. 2018a). Although it remains difficult to precisely predict the size and residence time of individual jams, the locations within the river corridor that tend to accumulate jams can be predicted with reasonable accuracy.

\section{Feedbacks Within Wood Regimes}

Interactions among recruitment, transport, and storage create nonlinear effects both within the wood regime and for the geomorphic and ecological effects of wood. Rapid recruitment via bank erosion can facilitate formation of closely spaced channel-spanning logjams that limit subsequent wood transport (Oswald and Wohl 2008). Wood jams create higher wood loads than dispersed pieces and wood jam spatial density regulates the efficiency 
of a reach at trapping wood in transport (Scott and Wohl 2018, Wohl et al. 2018b). The ability of some wood species to regenerate extends residence times through root anchorage, while the regenerating above-ground biomass acts as an additional retention structure for other wood pieces (Gurnell et al. 2001). Storage influences the rate and magnitude of wood decay by controlling the exposure and potential abrasion and decomposition of wood pieces (Merten et al. 2013). Wood decay also influences transport and storage as decaying wood pieces break or abrade and thus become more easily mobilized (Merten et al. 2013).

Feedbacks also create nonlinear physical and ecological effects associated with wood. Logjams can cause greater bed scour and deposition of fine sediment than an equivalent volume of dispersed wood pieces (Wohl 2017). Wood stored along the inside of a meander bend may facilitate greater sediment deposition than wood stored along the outside of the bend (Zen et al. 2017). Channel-spanning logjams that are closely spaced downstream can facilitate formation of secondary channels that significantly increase habitat abundance and biological productivity per unit length of valley (Herdrich et al. 2018, Venarsky et al. 2018).

The presence of these and other feedbacks between mobile and stored wood and river corridor process and form highlight the importance of considering wood in the context of an integrated wood regime that includes diverse aspects of recruitment, transport, and storage. Feedbacks are particularly important in creating nonlinear behavior in river corridors, including alternative states mediated by the presence or absence of wood (Supplemental Text 3) (Collins et al., 2012; Livers et al., 2018). Multi-year monitoring of storage from ground-based measurements or airborne imagery can show the potential variability in magnitude, duration, and mode of wood storage at one location and can inform transport dynamics by tracking wood that is imported into the storage zone, remains in storage, or is exported downstream (Boivin et al. 2015; Figure 4). This type of monitoring may be particularly effective at identifying feedbacks and thresholds.

\section{Target Wood Regimes}

In the following sections, we review how insight gained from natural wood regimes and understanding of river corridors can be used to identify target wood regimes that balance the benefits derived from wood in river corridors against the potential hazards created by wood. The first steps in this process are characterizing the contemporary wood regime, identifying differences between the natural and contemporary wood regime, and differentiating wood process domains within a river network.

\section{Characterizing Contemporary Wood Regimes}

Direct measurements and numerical and stochastic models can be used to characterize the different components of contemporary wood regimes, as discussed in the preceding sections. However, until more data are available to accurately parametrize mechanistic, multiscale models of wood regimes across regions (Scott and Wohl, 2018), characterizing wood regimes over broad spatial scales will remain difficult. Current efforts can best describe individual segments of river corridor that are defined based on consistent characteristics of flow, sediment, and wood regimes, as well as channel and floodplain morphology. 
A primary management challenge is that of comparing expected wood regime in natural conditions versus contemporary wood regime. The contemporary wood regime in many river networks is affected by flow regulation, land use in recruitment zones, vegetation and wood removal, or river engineering. One strategy for comparison is to consider basin-scale magnitude of wood recruitment, transport, and storage according to an expected maximum based on reference or historical conditions, and then assess the differences between observed and natural conditions (Ruiz-Villanueva et al. 2016, Senter et al. 2017). Observed differences can then be linked to changes in process, form, and function within the river corridor, and management actions can be designed to enhance wood-related benefits (Figure 5).

An ever-present challenge is that wood regimes at regional scales are idiosyncratic compared with water regimes, which can be inferred regionally with relatively straightforward models such as regional rating curves for discharge. Part of the idiosyncrasies of wood regimes are that many rivers, especially in human-altered watersheds, are supply limited with respect to wood. Even in unaltered watersheds, the details of the wood regime are strongly influenced by the location, age, and species characteristics (e.g., shape and size) of trees. These types of constraints presently prevent us from reaching the same level of quantitative accuracy that can be developed for water and sediment regimes. However, wood process domains can be used to spatially differentiate significant aspects of the wood regime within and among river networks.

\section{Wood Process Domains}

A geomorphic process domain is a spatially identifiable area characterized by distinct suites of processes (Montgomery 1999, Polvi et al. 2011). Wood process domains are parts of the river network with similar wood regime patterns (Wohl 2011) (Figure 3), but the criteria used to distinguish process domains can vary based on the component of the wood regime that is of most interest. Process domains can be used to distinguish high-relief portions of a network in which channels are confined and well-connected to adjacent hillslopes, for example, so that hillslope instability dominates large wood inputs (May and Gresswell 2003). In lower relief portions of the network, partly confined to unconfined channels can have predominantly autochthonous wood recruitment from the floodplain (Wohl et al. 2018b). Process domains can be useful in differentiating wood-transport-limited and supply-limited portions of the network (Wohl and Jaeger 2009). Process domains can also be designated based on portions of the river network in which channel physical complexity or fluvial transport of wood onto floodplains enhances storage (Wohl et al. 2018b) versus portions of the network in which minimal wood is stored.

\section{Managing for Target Wood Regimes}

Integrated models of wood recruitment, transport, and storage do not yet exist for most regions of the world. As these models continue to develop, they are likely to provide useful insights into wood regimes under changing conditions, including management of channel geometry and flow regime, changing climate, and progressive changes in forest cover associated with processes such as deforestation and afforestation. As the capability of models increases for simulating specific effects associated with the presence of wood, such as sediment deposition or pool formation (e.g., Eaton et al. 2012), the models can also be used to evaluate 
management scenarios based on differing wood loads or fluxes. For the most part, models are only currently available for regions with decades of basic research into wood dynamics and these data form the basis for model development and verification. The difficulties inherent in trying to quantify or model the natural wood regime, however, need not preclude management directed toward restoring a less altered wood regime that balances desired versus hazardous aspects of wood.

The widespread disruption of natural wood regimes suggests that the most effective approach to wood management in many regions is to strive for a target wood regime. In a management context, a target wood regime is one that results in a channel that maintains sufficient recruitment, storage, and transport (or decay) to sustain desirable geomorphic, hydrologic, social, and ecological characteristics without causing socio-economic losses beyond acceptable levels (Wohl et al. 2016) (Tables 2 and 3). These losses frequently stem from increased flood risk at narrow sections potentially obstructed by wood during floods but can also result from other modifications such as reduced hydropower production when reservoirs are removed to restore wood connectivity. In most scenarios, a target wood regime will reflect a human-altered condition in which altered water, sediment, and wood supplies vary within a range constrained by human activities such as changes in land cover and flow regime. In exceptional cases with minimal or no human alteration of the wood regime, management can be designed for a target wood regime that preserves the existing, natural wood regime (e.g., prohibiting timber harvest or channel engineering in an unaltered river corridor).

Process domains can be explicitly defined in a management context, such as in relation to hazards associated with infrastructure or human presence, with some high-risk portions of a river network managed for wood removal and other portions managed for wood retention (Piégay and Landon 1997, Wohl et al. 2016). Wood process domains can also be used as a tool to explore and map spatial transitions in wood regimes along a channel network and temporal changes in wood regimes through time in response to disturbance or changes in regional drivers such as geology, climate, or land use (Kramer and Wohl 2017).

All components of the wood regime play into developing a target wood regime, although constraints (e.g., infrastructure near rivers) may be imposed that limit certain aspects of the target wood regime. With regards to recruitment, a target wood regime should attempt to maximize sustainability of wood transport and storage by maintaining some mode of recruitment at a magnitude, frequency, duration, timing, and rate that is compatible with other aspects of the target wood regime. This should include riparian forest management that ensures a sufficient supply of wood, which can be characterized based on parameters such as tree-stand density and tree height.

The storage component of a target wood regime relates to desirable quantities of stored wood. This is highly dependent on context as governed by ecoregion and wood process domain (e.g., Dufour and Piégay 2009) and on timespan and sequence in time (e.g., years after the last disturbance that influenced wood recruitment or transport). Because storage naturally varies over time, a natural or target wood load cannot be represented by a single value.

The most common example of managing for quantity of stored wood involves introducing wood pieces or logjams that are fixed in place (e.g., Reich et al. 2003, Roni et al. 2015). This is typically used where continuing recruitment of new wood that is at least 
temporarily stable is unlikely to replace mobilized wood, and where mobile wood may create hazards for people and infrastructure. The most recent trend in restoring wood is sometimes called stage 0 restoration and involves wood that can move through time and is designed to create and maintain a multithread channel planform.

Reintroduction of wood to a river corridor is an example of active restoration. Passive restoration emphasizes creating and sustaining the conditions that result in wood recruitment, transport, and storage. Although more likely to be self-sustaining, passive restoration is not feasible in some river reaches because of existing constraints or lack of responsiveness of the river corridor to floods. Active and passive restoration of wood regime can be complementary, with different approaches used in different portions of a drainage network.

The common management approach of fixing all wood in place contradicts the idea of maintaining a dynamic wood regime by allowing for mobility in the form of recruitment and transport. Maintaining wood mobility is likely to be important for sustaining habitat and biodiversity within river corridors capable of reacting to the presence of wood through modification of river process and form (e.g., Sear et al. 2010). Mobile wood can be an integral component of floodplain or riparian disturbance regime by mechanically damaging or removing living plants and creating new germination sites (Johnson et al. 2000, Gurnell et al. 2001, Collins et al. 2012, Osei et al. 2015). Mobility can facilitate the presence of wood in varying stages of decay, which influences habitat and biodiversity within river corridors by providing substrate diversity for microbial and macroinvertebrate communities (Harmon et al. 1986). Fluxes of wood from rivers to marine ecosystems supply nutrients and create habitat from nearshore to deep-sea environments (Maser and Sedell 1994, Simenstad et al. 2003, Schwabe et al. 2015). Wood recruited via river transport and shoreline erosion also provides important habitat within lakes (Marburg et al. 2006, Kramer and Wohl 2015). The characteristics of river morphology become particularly important in the context of wood mobility because wood is naturally more mobile in some portions of a river network.

These documented effects of wood mobility suggest the importance of managing for dynamic rather than static wood loads within river corridors. Managing for wood dynamics is challenging because it requires identifying and managing for processes of wood recruitment and transport, which commonly involve wider and longer portions of a river network than the limited channel segments that are typically the focus of management (e.g., Boyer et al. 2003). In addition, the presence of infrastructure that could be damaged by mobile wood may require installation of special structures to limit downstream wood transport (Comiti et al. 2016, RuizVillanueva et al. 2016) or modifying structures such as bridges (DeCicco et al. 2018) to allow wood to pass. Such structures exist (Figure 6), however, and can be used if the presence of potentially mobile wood is an important consideration. Supplemental Text 4 discusses techniques that can be used to evaluate whether individual wood pieces or jams are likely to remain stable or become mobile.

For all aspects of a target wood regime, management actions will be effective when they are part of integrated basin management that considers the larger context and when specific actions are appropriate to the wood process domain. For example, reforesting upland hillslopes will not greatly change the wood regime unless hillslope mass movements are an important source of wood recruitment. Wood in a rapidly shifting braided river or a river with 
flashy discharge is likely to be more mobile under natural conditions than wood in a lowland river with limited hydrologic variability and cohesive, stable channel boundaries, so installation of stable wood structures in a braided or flashy river may not be appropriate. The widespread loss of old-growth forests and consequent absence of especially large, naturally stable wood pieces, on the other hand, may be compensated for by fixing some wood pieces in place. Another consideration is that wood is not equally effective in creating habitat, for example, in all river segments. Introducing wood pieces or logjams that are fixed in place (e.g., Reich et al. 2003, Roni et al. 2015) has the most utility in recruitment reaches where wood transport occurs rarely or in reaches where there is enough continuing recruitment of new wood to jam against the introduced wood and potentially replace wood that is mobilized. Anchored floodplain wood may also be more stable than wood within the active channel. Anchoring wood has utility where mobile wood may create hazards for people and infrastructure, but in some systems and with sufficiently large flows, these anchored pieces could be mobilized along with any anchoring hardware, creating greater hazards.

Of critical importance is recognizing that a reach of river corridor targeted for management is connected to upstream and downstream portions of the river network and adjacent uplands and thus can influence and be influenced by processes occurring outside of the reach. It is also critical to take into consideration that process and form in river corridors, including wood regimes, are dynamic, such that fluctuations will occur even if a consistent mean condition is present over the timespan of interest. Utilizing a wood regime framework, monitoring wood flux, and quantifying wood budgets can help river managers to identify reference, contemporary, and target wood regimes for a specific river reach. Finally, attention to the social context is critical for successful implementation of a target wood regime. This is likely to be most effective if considerations such as perceptions, social access to and use of a river, levels of acceptable risk, future trajectories of human influence, and interactions of human policies and regulations are included in analyses for the target wood regime.

\section{Conclusions}

River science now recognizes large wood as a primary driver of physical and biotic conditions in river corridors. This supports conceptualizing the natural wood regime, along with water and sediment, as the third leg of a tripod of physical processes that supports river science and management. The natural flow regime is enormously influential in river management and restoration because of growing recognition of the devastating effects of altered flow regimes on water quality and on aquatic and riparian biotic communities. Although it is impractical to completely restore natural flow regimes on many rivers, an understanding of the natural flow regime can be used to identify which aspects of flow regime may be critical to restoring lost or compromised ecosystem services, as well as to quantifying the extent of alteration of the present flow regime. Identification and restoration of the natural wood regime can also create substantial physical and ecological benefits. Forested river corridors that retain a natural wood regime illustrate how interactions among water, sediment, wood, and valley geometry create secondary effects such as peak flow attenuation, nutrient uptake, sediment and particulate organic matter storage, habitat abundance and diversity, and greater biomass of organisms per unit length of river corridor. The beneficial effects of wood in river corridors have largely been 
overlooked because of the widespread lack of abundant wood in forested river corridors. This reflects centuries of active wood removal from rivers, as well as diminished wood recruitment associated with changing land cover, reduced wood retention as river corridors have become more physically simple and homogeneous, and perceptions of wood in rivers as wasted or unsightly. Natural wood regimes are dynamic and challenging to characterize. However, river management that explicitly includes feasible targets for the wood regime, based on an understanding of the natural wood regime for a river catchment, can restore lost or diminished ecosystem services. Such management must be accompanied by efforts to change what are commonly negative public perceptions of wood in river corridors. Ultimately, river management that does not incorporate target wood regimes cannot sustain the physical and ecological attributes of rivers that people value.

\section{Acknowledgements}

This research was subjected to USGS review and approved for publication. Any use of trade, firm, or product names is for descriptive purposes only and does not imply endorsement by the U.S. Government. We appreciate insightful comments from David Leigh, Frederick Swanson, Stanley Gregory, and two anonymous reviewers. 


\section{References}

Abbe TB, Montgomery DR. 2003. Patterns and processes of wood debris accumulation in the Queets River basin, Washington. Geomorphology 51, 81-107.

Beckman ND, Wohl E. 2014. Carbon storage in mountainous headwater streams: the role of old-growth forest and logjams. Water Resources Research 50: 2376-2393.

Benacchio V, Piégay H, Buffin-Balanger T, Vaudor L. 2017. A new methodology for monitoring wood fluxes in rivers using a ground camera: Potential and limits. Geomorphology 279: 44-58.

Benda LE, Sias JC. 2003. A quantitative framework for evaluating the mass balance of in-stream organic debris. Forest Ecology and Management 172: 1-16.

Benke AC, Wallace JB. 1990. Wood dynamics in coastal plain backwater streams. Canadian Journal of Fisheries and Aquatic Sciences 47: 92-99.

Boivin M, Buffin-Belanger T, Piegay H. 2015. The raft of the Saint-Jean River, Gaspé (Québec, Canada): a dynamic feature trapping most of the wood transported from the catchment. Geomorphology 231: 270-280.

Boyer KL, Berg DR, Gregory SV. 2003. Riparian management for wood in rivers. In: Gregory SV, Boyer KL, Gurnell AM. (Eds.), The Ecology and Management of Wood in World Rivers. American Fisheries Society Symposium 37, pp. 407-420, Bethesda, MD.

Collins BD, Montgomery DR, Fetherson KL, Abbe TB. 2012. The floodplain large wood cycle hypothesis: a mechanism for the physical and biotic structuring of temperate forested alluvial valleys in the North Pacific coastal ecoregion. Geomorphology 139-140: 460-470.

Comiti F, Lucía A, Rickenmann D. 2016. Large wood recruitment and transport during large floods : a review. Geomorphology 269: 23-39.

Corenblit D, Davies NS, Steiger J, Gibling MR, Bornette G. 2015. Considering river structure and stability in the light of evolution: feedbacks between riparian vegetation and hydrogeomorphology. Earth Surface Processes and Landforms 40: 189-207.

Culp JM, Scrimgeour JG, Townsend GD. 1996. Simulated fine woody debris accumulations in a stream increase rainbow trout fry abundance. Transactions of the American Fisheries Society 125: 472-479.

De Cicco Pina N, Paris E, Ruiz-Villanueva V, Solari L, Stoffel M. 2018. In-channel wood-related hazards at bridges: A review. River Research and Applications. https://doi.org/10.1002/rra.3300

Dufour S, Piégay H. 2009. From the myth of a lost paradise to targeted river restoration: forget natural references and focus on human benefits. River Research and Applications 25: 568-581. 
Eaton BC, Hassan MA, Davidson SL. 2012. Modeling wood dynamics, jam formation, and sediment storage in a gravel-bed stream. Journal of Geophysical Research: Earth Surface 117: F00A05. doi:10.1029/2012JF002385

Fox M, Bolton S. 2007. A regional and geomorphic reference for quantities and volumes of instream wood in unmanaged forested basins of Washington State. North American Journal of Fisheries Management 27: 342-359.

Galia T, Ruiz-Villanueva V, Tichavský R, Šilhán K Horáček M, Stoffel M. 2018. Characteristics and abundance of large and small instream wood in a Carpathian mixed-forest headwater basin. Forest Ecology and Management 424. https://doi.org/10.1016/j.foreco.2018.05.031

Gregory SV, Meleason MA, Sobota DJ. 2003. Modeling the dynamics of wood in streams and rivers. In: Gregory SV, Boyer KL, Gurnell AM. (Eds.), The Ecology and Management of Wood in World Rivers. American Fisheries Society Symposium 37, pp. 315-335 Bethesda, MD.

Gurnell AM. 2003. Wood storage and mobility. In: Gregory SV, Boyer KL, Gurnell AM. (Eds.), The ecology and management of wood in world rivers, Bethesda, MD, American Fisheries Society, pp. 75-91.

Gurnell AM. 2007. Analogies between mineral sediment and vegetative particle dynamics in fluvial systems. Geomorphology 89: 9-22.

Gurnell AM. 2013. Wood in fluvial systems. In: John F. Shroder (ed.) Treatise on Geomorphology, Vol. 9, pp. 163-188. San Diego: Academic Press.

Gurnell AM. 2014. Plants as river system engineers. Earth Surface Processes and Landforms, 39: 4-25.

Gurnell AM, Petts GE. 2002. Island-dominated landscapes of large floodplain rivers, a European perspective. Freshwater Biology 47: 581-600.

Gurnell AM, Petts GE, Hannah DM, Smith DPG, Edwards PJ, Kollmann J, Ward JV, Tockner K. 2001. Riparian vegetation and island formation along the gravel-bed Fiume Tagliamento, Italy. Earth Surface Processes and Landforms 26: 31-62.

Gurnell A, Tockner K, Edwards PJ, Petts GE. 2005. Effects of deposited wood on biocomplexity of river corridors. Frontiers in Ecology and Environment 3: 377-382.

Gurnell AM, Bertoldi W, Corenblit D. 2012. Changing river channels: the roles of hydrological processes, plants and pioneer landforms in humid temperate, mixed load, gravel bed rivers. Earth Science Reviews 111: 129-141.

Guyette RP, Dey DC, Stambaugh MC. 2008. The temporal distribution and carbon storage of large oak wood in streams and floodplain deposits. Ecosystems 11: 643-653. 
Harmon ME, Franklin JF, Swanson FJ, Sollins P, Gregory SV, Lattin JD, Anderson NH, Cline SP, Aumen NG, Sedell JR, Lienkaemper GW, Cromack K, Cummins JW. 1986. Ecology of coarse woody debris in temperate ecosystems. Advances in Ecological Research 15: 133-302.

Herdrich AT, Winkleman DL, Venarsky MP, Walters DM, Wohl E. 2018. The loss of large wood affects Rocky Mountain trout populations. Ecology of Freshwater Fish 27: 1023-1036.

Hynes HBN. 1975. The stream and its valley. Internationale Vereinigung fur Theoretische und Angewandte Limnologie Verhandlungen 19: 1-15.

Johnson SL, Swanson FJ, Grant GE, Wondzell SM. 2000. Riparian forest disturbances by a mountain flood - the influence of floated wood. Hydrological Processes 14: 3031-3050.

Keller EA, MacDonald A, Tally T, Merrit NJ. 1995. Effects of large organic debris on channel morphology and sediment storage in selected tributaries of Redwood Creek, northwestern California. U.S. Geological Survey Professional Paper 1454, P 29 pp.

Kraft CE, Warren DR, Keeton WS. 2011. Identifying the spatial pattern of wood distribution in northeastern North American streams. Geomorphology 135, 1-7.

Kramer N, Wohl E. 2015. Driftcretions: The legacy impacts of driftwood on shoreline morphology. Geophysical Research Letters 42: 5855-5864.

Kramer N, Wohl E. 2017. Rules of the road: a qualitative and quantitative synthesis of large wood transport through drainage networks. Geomorphology 279: 74-97.

Lancaster ST, Hayes SK, Grant GE. 2001. Modeling sediment and wood storage and dynamics in small mountainous watersheds. In: Dorava JM, Montgomery DR, Palcsak BB, Fitzpatrick FA.

(Eds.), Geomorphic Processes and Riverine Habitat. American Geophysical Union Press, Washington, DC, pp. 85-102.

Lane EW. 1955. The importance of fluvial morphology in hydraulic engineering. American Society of Civil Engineers Proceedings Separate 81: 1-17.

Lassettre NS, Piégay H, Dufour S, Rollet AJ. 2008. Decadal changes in distribution and frequency of wood in a free meandering river, the Ain River, France. Earth Surface Processes and Landforms 33: 1098-1112.

Le Lay YF, Piégay H, Moulin B. 2013. Wood entrance, deposition, transfer and effects on fluvial forms and processes: problem statements and challenging issues. Treatise on Geomorphology, v. 12 , pp. $20-36$.

Lininger KB, Wohl E, Sutfin NA, Rose JR. 2017. Floodplain downed wood volumes: a comparison across three biomes. Earth Surface Processes and Landforms 42: 1248-1261. 
Livers B, Wohl E, Jackson KJ, Sutfin NA. 2018. Historical land use as a driver of alternative states for stream form and function in forested mountain watersheds of the Southern Rocky Mountains. Earth Surface Processes and Landforms 43: 669-684.

Lucía A, Comiti F, Borga M, Cavalli M, Marchi L. 2015. Dynamics of large wood during a flash flood in two mountain catchments. Natural Hazards Earth Syst. Sci. Discuss. 3: 1643-1680.

MacVicar B, Piégay H. 2012. Implementation and validation of video monitoring for wood budgeting in a wandering piedmont river, the Ain River (France). Earth Surface Processes and Landforms 37: 1272-1289.

Marburg AE, Turner MG, Kratz TK. 2006. Natural and anthropogenic variation in coarse wood among and within lakes. Journal of Ecology 94: 558-568.

Maser C, Sedell JR. 1994. From the forest to the sea: The ecology of wood in streams, rivers, estuaries and oceans. St. Lucie Press, Delray Beach, Florida, USA.

May CL, Gresswell RE. 2003. Processes and rates of sediment and wood accumulation in headwater streams of the Oregon Coast Range, USA. Earth Surface Processes and Landforms 28: 409-424.

Mazzorana B, Hubl J, Zischg A, Largiader A. 2011. Modelling woody material transport and deposition in alpine rivers. Natural Hazards 56: 425-449.

Merten EC, Vaz PG, Decker-Fritz JA, Finlay JC, Stefan HG. 2013. Relative importance of breakage and decay as processes depleting large wood from streams. Geomorphology 190: 40-47.

Millington CE, Sear DA. 2007. Impacts of river restoration on small-wood dynamics in a lowgradient headwater stream. Earth Surface Processes and Landforms 32: 1204-1218.

Montgomery DR. 1999. Process domains and the river continuum. Journal of the American Water Resources Association 35:397-410.

Montgomery DR, Collins BD, Buffington JM, Abbe TB. 2003. Geomorphic effects of wood in rivers. In: Gregory SV, Boyer KL, Gurnell AM. (Eds.), The Ecology and Management of Wood in World Rivers. American Fisheries Society Symposium 37, pp. 21-47 Bethesda, MD.

Nanson GC, Barbetti M, Taylor G. 1995. River stabilisation due to changing climate and vegetation during the late Quaternary in western Tasmania, Australia. Geomorphology 13: 145158.

Opperman JJ, Meleason M, Francis RA, Davies-Colley R. 2008. "Livewood": Geomorphic and ecological functions of living trees in river channels. BioScience 58: 1069-1078.

Osei NA, Gurnell AM, Harvey GL. 2015. The role of large wood in retaining fine sediment, organic matter and plant propagules in a small, single-thread forest river. Geomorphology 235: 77-87. 
Oswald EB, E Wohl. 2008. Wood-mediated geomorphic effects of a jökulhlaup in the Wind River Mountains, Wyoming. Geomorphology 100: 549-562.

Phillips JD, Park L. 2009. Forest blowdown impacts of Hurricane Rita on fluvial systems. Earth Surface Processes and Landforms 34: 1069-1081.

Piégay H. 1993. Nature, mass and preferential sites of coarse woody debris deposits in the Lower Ain valley (Mollon reach), France. Regulated Rivers: Research and Management 8, 359372.

Piégay H, Landon N. 1997. Promoting ecological management of riparian forests on the Drôme River, France. Aquatic Conservation: Marine and Freshwater Ecosystems 7: 287-304.

Piégay H, Moulin B, Hupp CR. 2017. Assessment of transfer patterns and origins of in-channel wood in large rivers using repeated field surveys and wood characterisation (the Isère River upstream of Pontcharra, France). Geomorphology 279: 27-43.

Poff NL, Allan JD, Bai, MB, Karr JR, Prestegaard KL, Richter BD, Sparks RE, Stromberg JC. 1997. The natural flow regime. BioScience 47: 769-784.

Polvi LE, Wohl EE, Merritt DM. 2011. Geomorphic and process domain controls on riparian zones in the Colorado Front Range. Geomorphology 125: 504-516.

Reich M, Kershner JL, Wildman RC. 2003. Restoring streams with large wood: a synthesis. In: Gregory SV, Boyer KL, Gurnell AM. (Eds.), The Ecology and Management of Wood in World Rivers. American Fisheries Society Symposium 37, pp. 355-366 Bethesda, MD.

Richmond AD, Fausch KD. 1995. Characteristics and function of large woody debris in subalpine Rocky Mountain streams in northern Colorado. Canadian Journal of Fisheries and Aquatic Sciences 52: 1789-1802.

Roni P, Beechie T, Pess G, Hanson K. 2015. Wood placement in river restoration: fact, fiction, and future direction. Canadian Journal of Fisheries and Aquatic Sciences 72: 466-478.

Ruiz-Villanueva V, Blade E, Sanchez-Juny M, Marti-Cardona B, Diez-Herrero A, Bodoque JM. 2014. Two-dimensional numerical modeling of wood transport. Journal of Hydroinformatics 16 : 1077-1096.

Ruiz-Villanueva V, Piégay H, Gurnell AM, Marston RA, Stoffel M. 2016. Recent advances quantifying the large wood dynamics in river basins: New methods and remaining challenges. Reviews Geophysics 54: 611-652.

Ruiz-Villanueva V, Badoux A, Rickenmann D, Böckli M, Schläfli S, Steeb N, Stoffel M, Rickli C, 2018. Impacts of a large flood along a mountain river basin: unravelling the geomorphic response and large wood budget in the upper Emme River (Switzerland). Earth Surface Dynamics Discuss. 1-42. 
Sawyer AH, Cardenas MB, Buttles J. 2012. Hyporheic temperature dynamics and heat exchange near channel-spanning logs. Water Resources Research 48: W01529.

http://dx.doi.org/10.1029/2011WR011200.

Scott DN, Wohl E. 2018. Natural and anthropogenic controls on wood loads in river corridors of the Rocky, Cascade, and Olympic Mountains, USA. Water Resources Research.

Sear DA, Millington CE, Kitts DR, Jeffries R. 2010. Logjam controls on channel: floodplain interactions in wooded catchments and their role in the formation of multichannel patterns. Geomorphology 116: 305-319.

Senter A, Pasternack G, Piegay H, Vaughan M. 2017. Wood export prediction at the watershed scale. Earth Surface Processes and Landforms 42, 2377-2392.

Schumm SA. 1968. Speculations concerning paleohydrologic controls of terrestrial sedimentation. Geological Society of America Bulletin 79: 1573-1588.

Schwabe E, Bartsch I, Blazewicz-Paszkowycz M, Brenke N, Chernyshev AV, Elsner NO, Fischer V, Fazdzewska A, Malyutina MV, Miljutin D, Muljutina M, Kamenev GM, Karanovic I, Maiorova A, Wurzberg L. 2015. Wood-associated fauna collected during the KuramBio-expedition in the North West Pacific. Deep-Sea Research II 111: 376-388.

Sedell JR, Froggatt JL. 1984. Importance of streamside forests to large rivers: The isolation of the Willamette River, Oregon, U.S.A., from its floodplain by snagging and streamside forest removal. Verhandlungen. Internationale Vereinigung fur Theoretische und Angewandte Limnologie 22: 1828-1834.

Simenstad CA, Wick A, Van De Wetering S, Bottom DL. 2003. Dynamics and ecological functions of wood in estuarine and coastal marine ecosystems. In: Gregory SV, Boyer KL, Gurnell AM. (Eds.), The Ecology and Management of Wood in World Rivers. American Fisheries Society Symposium 37, pp. 265-277 Bethesda, MD.

Simpston RR, Mapleston AJ. 2002. Movements and habitat by the endangered Australian freshwater Mary River cod, Maccullochella peelii mariensis. Environmental Biology of Fishes 65: 401-410.

Sutfin NA, Wohl EE, Dwire KA. 2016. Banking carbon: a review of organic carbon storage and physical factors influencing retention in floodplains and riparian ecosystems. Earth Surface Processes and Landforms 41: 38-60.

Triska FJ. 1984. Role of wood debris in modifying channel geomorphology and riparian areas of a large lowland river under pristine conditions: a historical case study. Verhandlungen Internationale Verein Limnologie 22: 1876-1892. 
Turowski JM, Badoux A, Bunte K, Rickli C, Federspiel N, Jochner M. 2013. The mass distribution of coarse particulate organic matter exported from an Alpine headwater stream. Earth Surface Dynamics 1: 1-11.

Van der Nat D, Tockner K, Edwards PJ, Ward JV. 2003. Large wood dynamics of complex Alpine river floodplains. Journal of the North American Benthological Society 22: 35-50.

Venarsky MP, Walters DM, Hall RO, Livers B, Wohl E. 2018. Shifting stream planform state decreases stream productivity yet increases riparian animal production. Oecologia 187: 167180.

Wohl E. 2011. Seeing the forest and the trees: wood in stream restoration in the Colorado Front Range, United States. In: Stream Restoration in Dynamic Fluvial Systems: Scientific Approaches, Analyses, and Tools. American Geophysical Union Press, Washington, DC, pp. 399-418.

Wohl E. 2013. Floodplains and wood. Earth-Science Reviews 123: 194-212.

Wohl E. 2014. A legacy of absence: wood removal in U.S. rivers. Progress in Physical Geography 38: 637-663.

Wohl E. 2017. Bridging the gaps: an overview of wood across time and space in diverse rivers. Geomorphology 279: 3-26.

Wohl E, Jaeger K. 2009. A conceptual model for the longitudinal distribution of wood in mountain streams. Earth Surface Processes and Landforms 34: 329-344.

Wohl E, Bledsoe BP, Jacobson RB, Poff NL, Rathburn SL, Walters DM, Wilcox AC. 2015. The natural sediment regime in rivers: broadening the foundation for ecosystem management. BioScience 65: 358-371.

Wohl E, Bledsoe BP, Fausch KD, Kramer N, Bestgen KR, Gooseff MN. 2016. Management of large wood in streams: an overview and proposed framework for hazard evaluation. Journal of the American Water Resources Association 52: 315-335.

Wohl E, Scott DN. 2017. Wood and sediment storage and dynamics in river corridors. Earth Surface Processes and Landforms 42: 5-23.

Wohl E, Lininger KB, Fox M, Baillie BR, Erskine WD. 2017. Instream large wood loads across bioclimatic regions. Forest Ecology and Management 404: 370-380.

Wohl E, Cadol D, Pfeiffer A, Jackson K, Laurel D. 2018a. Distribution of large wood within river corridors in relation to flow regime in the semiarid western US. Water Resources Research 54: 1890-1904.

Wohl E, Scott DN, Lininger KB. 2018b. Spatial distribution of channel and floodplain large wood in forested river corridors of the Northern Rockies. Water Resources Research.

https://doi.org/10.1029/2018WR022750 
Zalamea M, Gonzalez G, Ping CL, Michaelson G. 2007. Soil organic matter dynamics under decaying wood in a subtropical wet forest: effect of tree species and decay stage. Plant and Soil 296: 173-185.

Zen S, AM Gurnell, G Zolezzi, N Surian. 2017. Exploring the role of trees in the evolution of meander bends: the Tagliamento River, Italy. Water Resources Research 53, doi:10.1002/2017WR020561. 


\section{Figures}

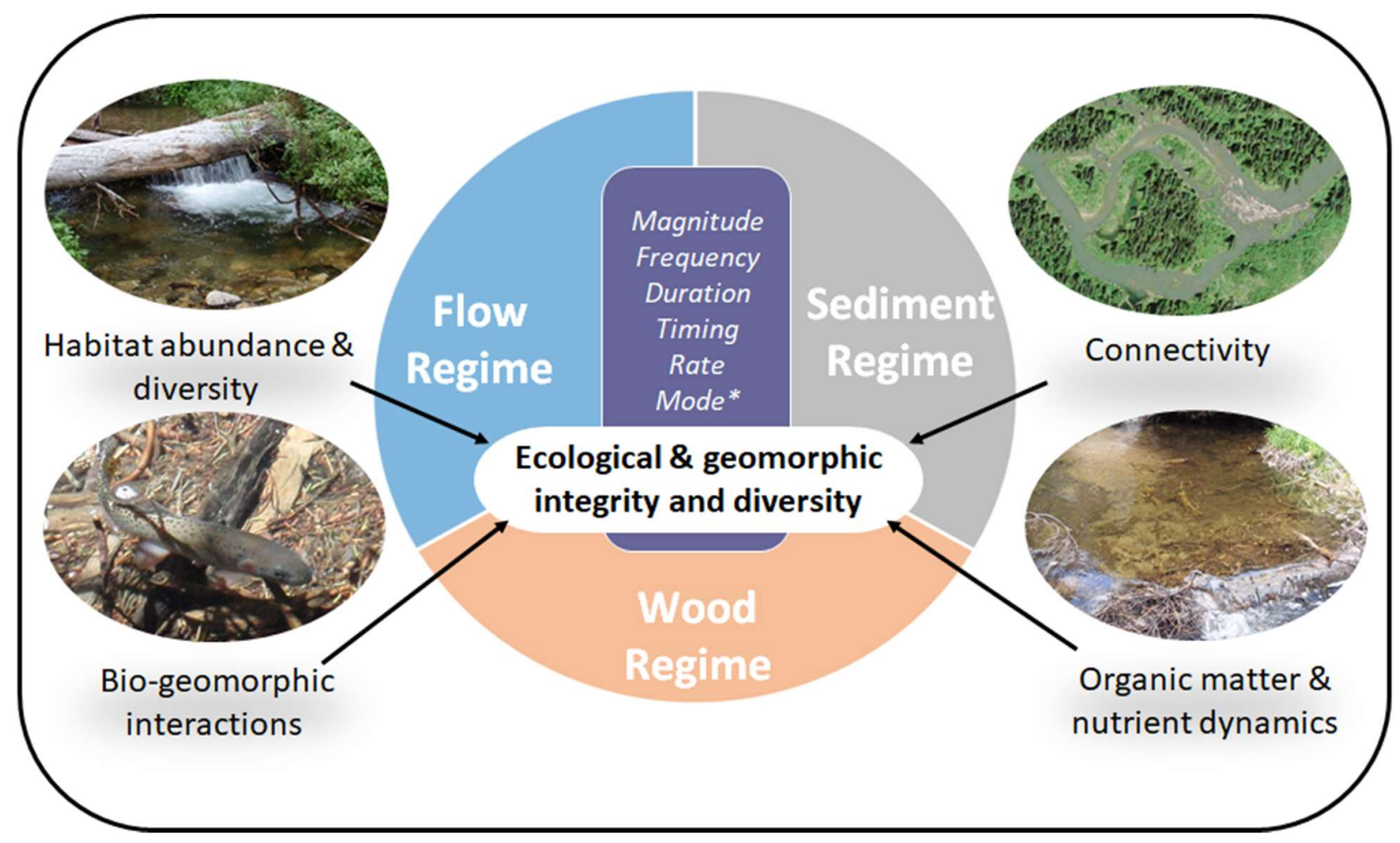

Figure 1. Characteristics of the river corridor influenced by interactions among water, sediment, and wood. Characteristics listed around the margins (e.g., physical habitat template) are influenced by the presence of mobile and stored wood. In the central box, mode* refers only to the wood regime. 

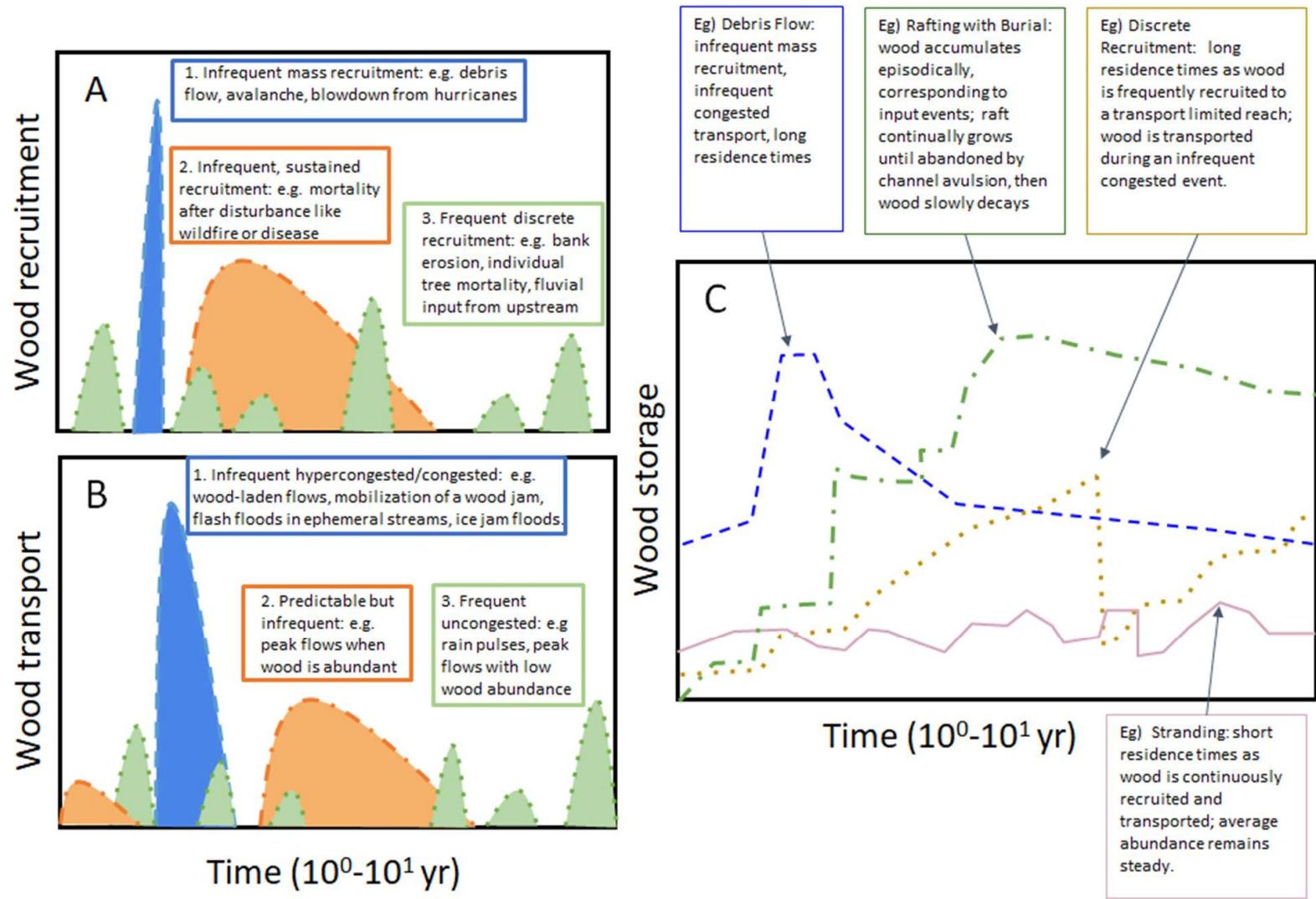

Figure 2. Hypothetical examples of wood recruitment (A), transport (B), and storage (C) regimes through time. Regimes are illustrative: substantial variability may exist that is not represented here. Wood storage reflects combined interactions between different recruitment and transport regimes. We present expected patterns of storage regimes through time associated with four of the example process domains in Figure 3. 


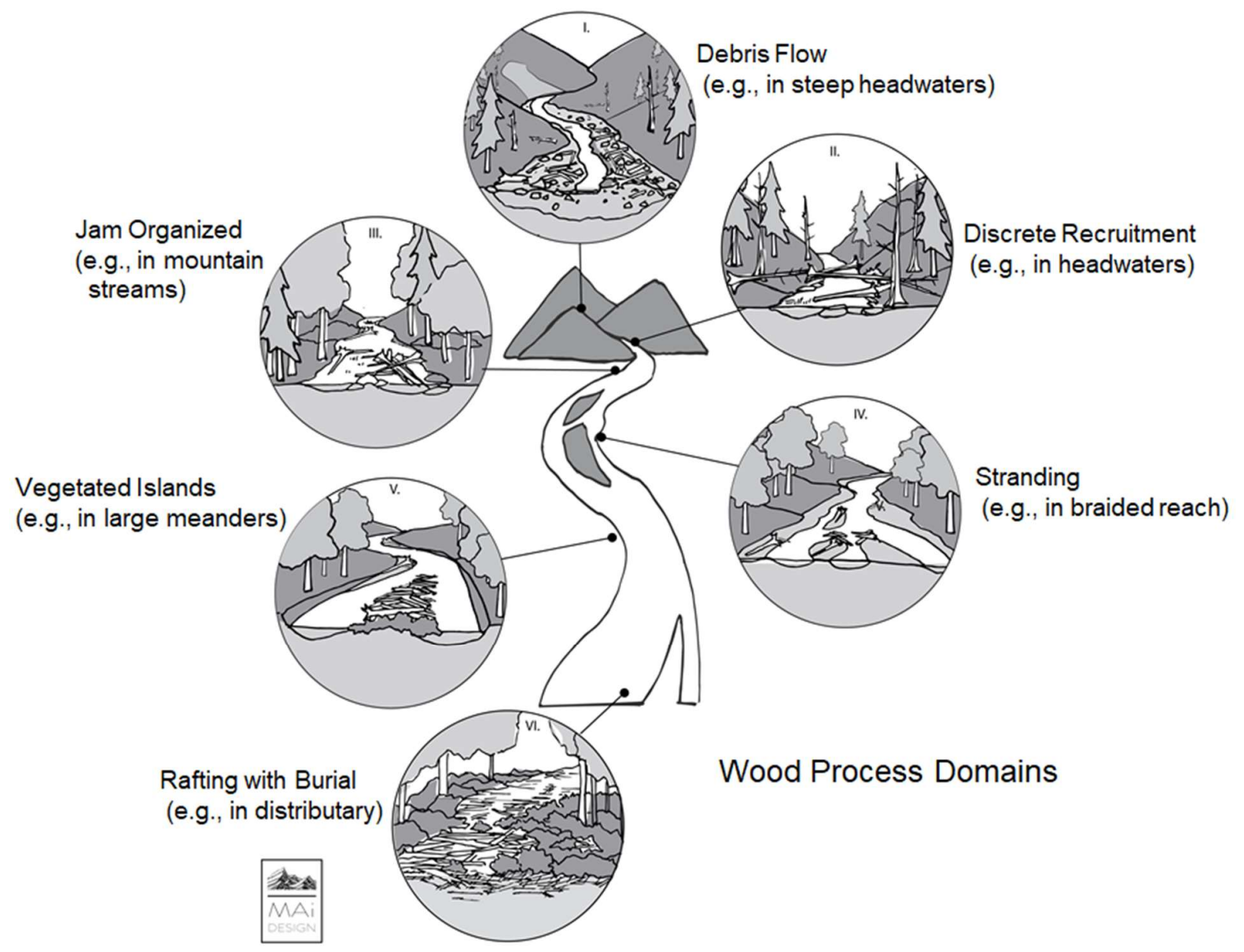

Figure 3. Hypothetical wood process domains along a river continuum. Each example domain has defining wood regime characteristics (Table 1 ) that result in a distinct regime over a specified time (Fig 2). Domains depicted are not intended to present a complete representation of all process domains and are not necessarily mutually exclusive. Furthermore, each domain does not necessarily encompass all components of the regime. I) Debris flow: wood is delivered infrequently en masse with long to permanent residence times. II) Discrete recruitment: recruitment of individual trees left dispersed in situ, over time leads to abundant storage due to limited transport capacity. III) Jam organized: flow is sufficient and frequent enough to mobilize and deflect pieces over short transport durations into concentrated jam features. IV) Stranding: dispersed wood is stranded on bars and margins as flows recede, transport timing and duration are predictably associated with flow level and frequency. V) Vegetated islands: wood is frequently floated and transported for long durations until concentrated at deposition sites, such as the heads of islands, facilitating re-vegetation and island expansion. VI) Rafting with burial: large concentrated rafts obstruct channels, long residence times interact with depositional environments to facilitate abundant accumulation, re-vegetation, and wood burial. Illustrations by MAi Design Ilc (www.maisierichards.com). 

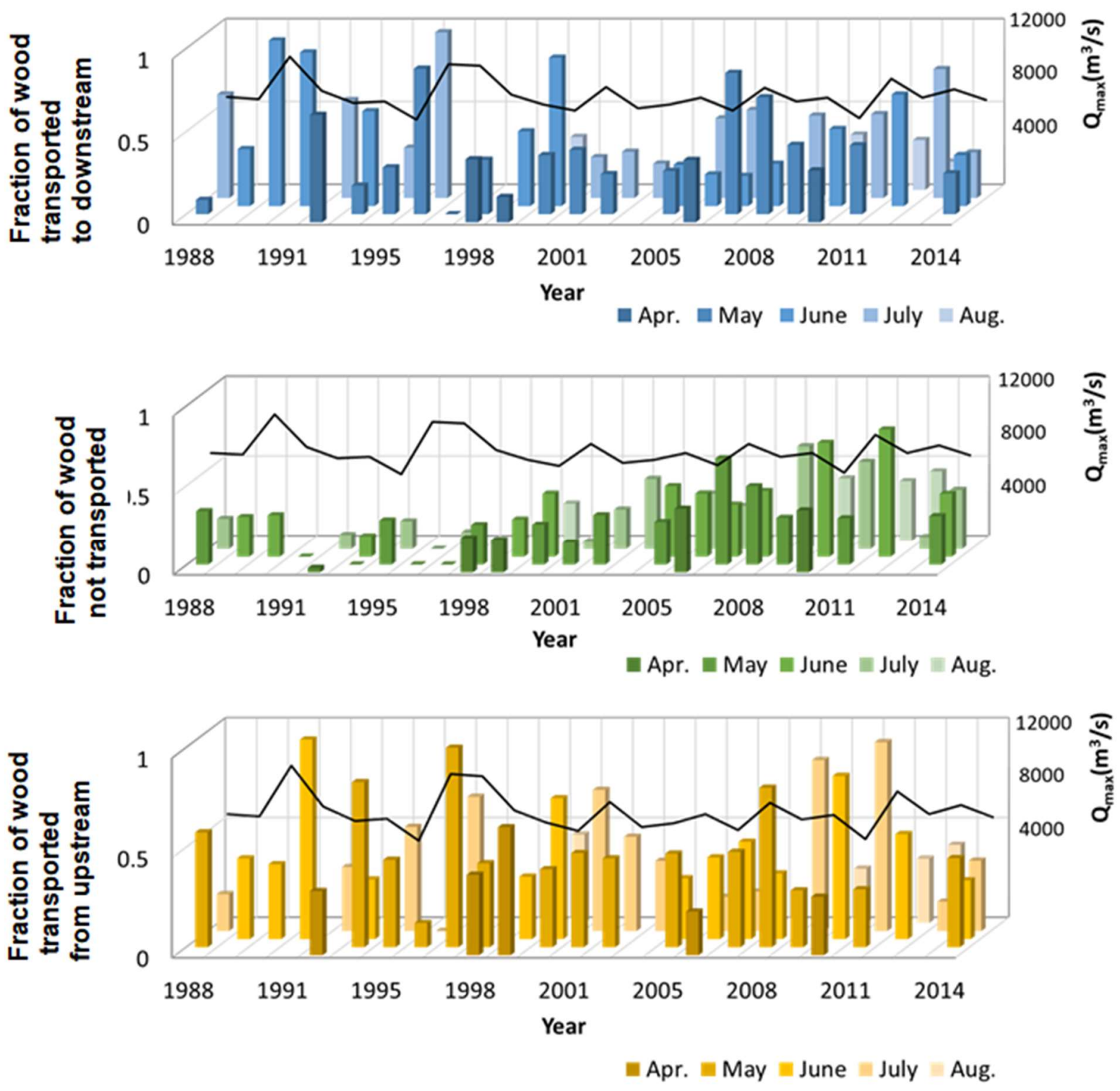

Figure 4. Time series showing fluctuation in proportion of wood entering storage, remaining in storage, or leaving storage from 1988 to 2014 within wood jams on islands in the Slave River, northern Canada (data from Kramer and Wohl 2017). Maximum peak discharge for each year on the $y$-axis, indicated by black line, is the same for all plots. 


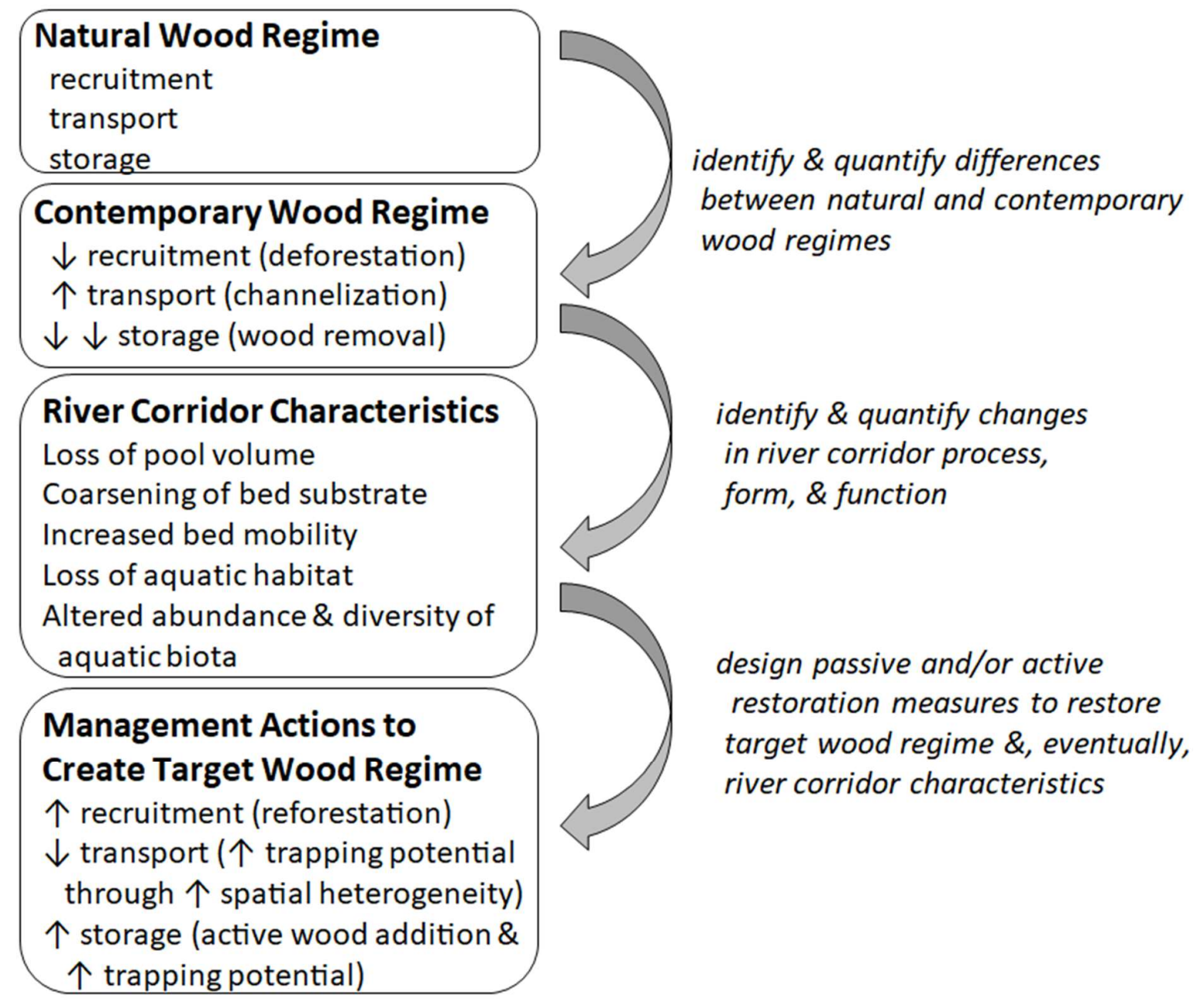

Figure 5. Flow chart outlining suggested procedure for developing a target wood regime. In this hypothetical example, the contemporary wood regime differs from a natural wood regime. Reduced recruitment because of deforestation and declining wood supply and increased transport because of channelization and loss of wood-trapping potential within the channel result in greatly decreased wood storage in the river corridor and associated alteration in river corridor characteristics. Management actions that restore wood supply through reforestation and increase trapping potential by enhancing the physical complexity of the channel and floodplain geometry can reduce wood transport and increase storage, helping to restore lost river form and function. 

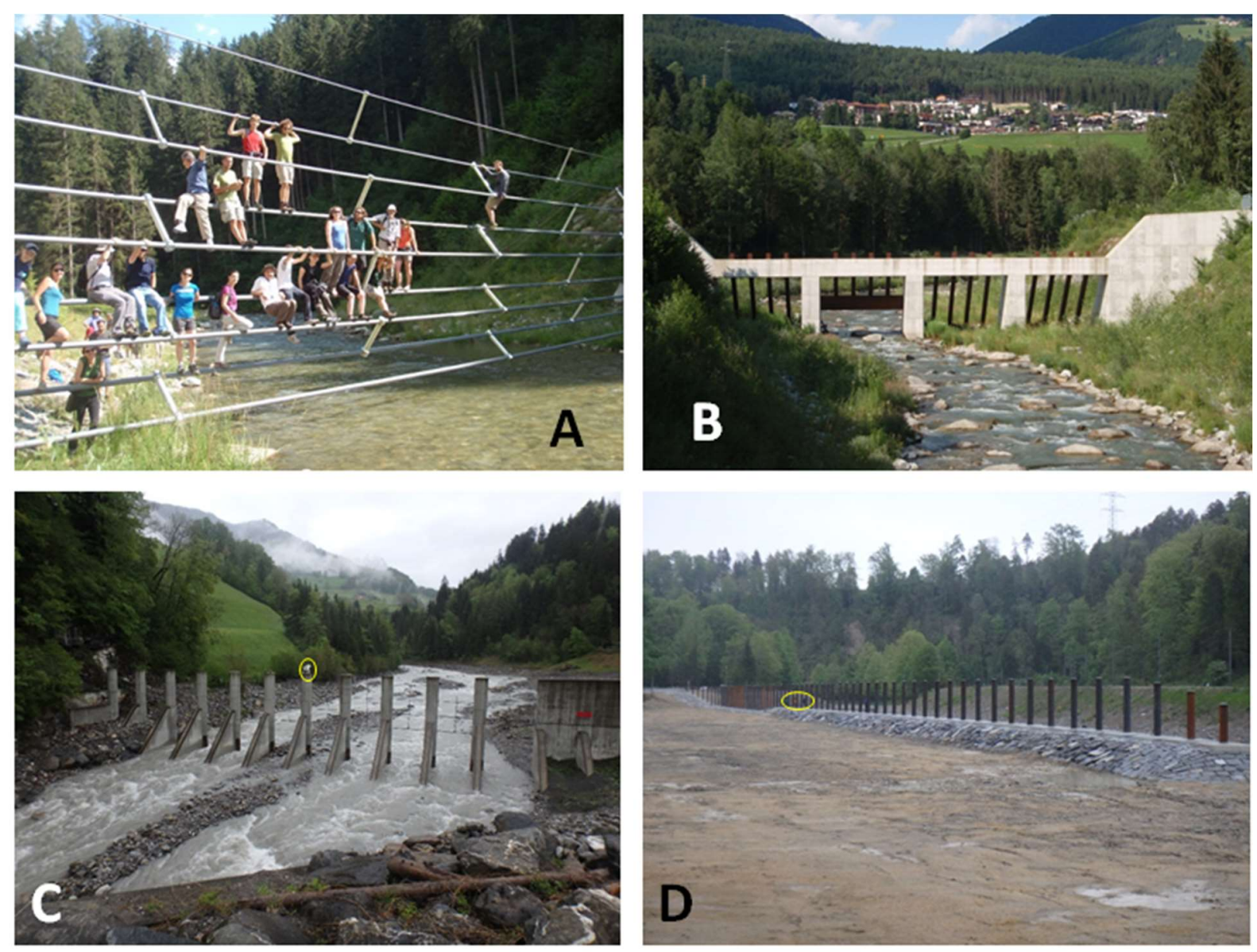

Figure 6. Examples of structures used to limit downstream mobility of wood. A and B: Rienz River, Italy; C: Chiene River, Switzerland (chair outlined in yellow for scale); D: Sihl River, Switzerland (people outlined in yellow for scale). The structure on the Sihl River is unique in size and design. It is installed parallel to the flow in the outer bend of a meander to retain wood (which might otherwise reach the City of Zurich), but allow sediment to be transported. 
2 Table 1. Components of wood regimes with respect to recruitment, transport, and storage.

\begin{tabular}{llll}
\hline & Recruitment & Transport & Storage \\
\hline Magnitude & $\begin{array}{l}\text { Mass } \\
\text { Individual }\end{array}$ & $\begin{array}{l}\text { Hypercongested/congested/ } \\
\text { semicongsted/uncongested }\end{array}$ & $\begin{array}{l}\text { Abundant } \\
\text { Minimal }\end{array}$ \\
\hline Frequency & $\begin{array}{l}\text { Frequent } \\
\text { Infrequent }\end{array}$ & $\begin{array}{l}\text { Frequent } \\
\text { Infrequent }\end{array}$ & Frequent \\
\hline Duration & $\begin{array}{l}\text { Short recruitment time } \\
\text { (episodic) }\end{array}$ & $\begin{array}{l}\text { Short transport time } \\
\text { Long transport time }\end{array}$ & Short residence time (mobile or \\
& $\begin{array}{l}\text { Long recruitment time } \\
\text { (continuous) }\end{array}$ & $\begin{array}{l}\text { quick to decay) } \\
\text { Long residence time (immobile or } \\
\text { slow to decay) }\end{array}$ \\
\hline Timing & $\begin{array}{l}\text { Predictable } \\
\text { Unpredictable }\end{array}$ & $\begin{array}{l}\text { Predictable } \\
\text { Unpredictable }\end{array}$ & Predictable \\
\hline Rate & $\begin{array}{l}\text { Rapid delivery } \\
\text { Slow delivery }\end{array}$ & $\begin{array}{l}\text { Rapid transport } \\
\text { Slow transport }\end{array}$ & $\begin{array}{l}\text { Rnpid change } \\
\text { Slow change }\end{array}$ \\
\hline Mode & $\begin{array}{l}\text { En masse } \\
\text { Sliding/rolling } \\
\text { Falling (snapping, leaning) } \\
\text { Biotic addition (beaver, } \\
\text { human) }\end{array}$ & $\begin{array}{l}\text { Floating (limited influence } \\
\text { from obstructions) } \\
\text { Deflecting (influenced by } \\
\text { obstructions) } \\
\text { Dragging (sliding, rolling) }\end{array}$ & $\begin{array}{l}\text { Dispersed (ramp, bridge, parallel, } \\
\text { oblique) } \\
\text { Concentrated (channel-spanning, } \\
\text { partial, floodplain, raft) } \\
\text { Buried }\end{array}$ \\
\hline
\end{tabular}

3 
6 Table 2. Example management strategies for attaining a target wood regime.

\section{Passive restoration}

Cessation or limits on

deforestation (wood recruitment)

removal of downed wood in the river corridor (transport, storage)

river engineering (recruitment, transport, storage)

flow regulation (recruitment, transport, storage)

Riparian forest management (e.g., planting, selective thinning or felling) to alter recruitment rate and piece characteristics

Removal of bank erosion mitigation measures to promote wood recruitment

Channel and floodplain design to control roughness and potential wood-trapping features such as bars and side channels

Modified design for infrastructure such as bridges or dams that influence wood regime

Altered regulatory framework that recognizes importance of presence of wood in river corridor

\section{Active restoration}

Reintroduction of either potentially mobile or fixed wood within river corridor

Beaver habitat enhancement or reintroduction

7 
Table 3. Examples of wood-focused management actions and associated effects that could be targeted as part of managing for a

10 target wood regime

\section{Management action}

Emplacing stationary logjams or maintaining wood fluxes that create logjams in the channel, with associated bed scour \& backwater effects, and pressure gradients that drive hyporheic exchange

\section{Effects \& example references}

Increased

pool volume \& salmonids (Richmond \& Fausch 1995, Herdrich et al.

2018; see supplemental text 1 for additional references)

hyporheic exchange flow (Sawyer et al. 2012)

snag habitat (Simpson \& Mapleston 2002)

sediment storage (Wohl \& Scott 2017)

organic carbon storage (Beckman \& Wohl 2014)
Emplacing stationary wood pieces or logjams or maintaining wood fluxes that create logjams in regularly inundated portions of the floodplain

Maintaining wood fluxes that create logjams, \& associated bars, islands, avulsion, \& secondary channels

Maintaining wood fluxes that deposit wood on floodplain through time, creating stored wood in differing stages of decay
Increased macroinvertebrate habitat (Benke \& Wallace 1990)

Increased organic carbon storage (Sutfin et al. 2016)

Increased habitat for terrestrial invertebrates, amphibians, reptiles, small animals, \& birds (Harmon et al. 1986; see references in Wohl et al. 2016)

Increased channel planform diversity (Collins et al. 2012)

Increased soil floodplain moisture \& fertility (Zalamea et al. 2007) 


\section{Supplemental Text 1. Wood budgets}

Benda and Sias (2003) proposed a basic form for a wood budget designed to be applied to a river channel:

$\Delta S=\left[L_{i}-L_{o}+Q_{i} / \Delta x-Q_{o} / \Delta x-D\right] \Delta t$

in which $\Delta S$ is the change in storage within a channel reach of length $x$ over time interval $t$, with $S$ commonly expressed as volume of wood per surface area of channel or length of channel (e.g., $\mathrm{m}^{3} / \mathrm{ha}$ or $\left.\mathrm{m}^{3} / \mathrm{m}\right) . L_{i}$ is lateral inputs to the channel and $L_{o}$ represents lateral outputs to the floodplain. $Q_{i}$ represents fluvial transport of large wood into the channel reach, including tributary inputs, and $Q_{0}$ fluvial transport out of the channel reach. $D$ is decay, which here includes breakage and abrasion that reduce large wood piece size and residence time within the channel.

Benda and Sias (2003) proposed rate equations for most of the terms in equation in (1). In particular, the variable $L_{i}$ can be further conceptualized as resulting from several individual processes (Benda and Sias 2003):

$L_{i}=I_{m}+I_{f}+I_{b e}+I_{s}+I_{e}+I_{t}+I_{b v}$

in which $I_{m}$ is individual tree mortality, $l_{f}$ is mass mortality, $l_{b e}$ represents large wood recruitment via bank erosion that recruits living trees, $l_{s}$ is recruitment via hillslope instability, $l_{e}$ describes large wood recruitment of both buried and downed, dead surface wood via floodplain erosion, $l_{t}$ is tributary inputs to the mainstem, and $I_{b v}$ represents beaver-recruited large wood in rivers of the northern hemisphere (Wohl 2017).

Equations (1) and (2) were developed primarily for application to timespans of centuries, as reflected by the inclusion of terms for wood decay and individual tree mortality (Comiti et al. 2016). These equations also focus on the channel rather than the entire river corridor, but can be recast to include the channel and floodplain:

$\Delta S=\left[L_{i}+I_{a}+Q_{i} / \Delta x-Q_{o} / \Delta x-D\right] \Delta t$

in which $\Delta S, x, t, Q_{i}, Q_{o}$, and $D$ are as in equation (1). $L_{i}$ is lateral inputs to the river corridor (primarily $I_{s}$ in equation 2 , as well as $I_{f}$ occurring on adjacent uplands) and $I_{a}$ represents autochthonous inputs within the river corridor that convert living trees or snags to downed, dead wood $\left(I_{m}, l_{f}, l_{b e}, l_{e}\right.$, and $l_{b v}$ in equation 2).

Wood budgets developed for an entire river network or for use during a single flood might more appropriately focus on volumes of wood recruited and transported (e.g., Comiti et al. 2016). This approach is more directly analogous to the flow characteristics quantified when describing a natural flow regime. Lucía et al. 2015 and Comiti et al. 2016 proposed an adapted equation to describe wood dynamics within a reach in terms of volume:

$V_{o, d s}=V_{i, u s}+V_{i, L S}+V_{i, L F}-V_{d, L}$

in which downstream exported wood volume $\left(V_{o, d s}\right)$ during a flood derives from the volume of large wood arriving from the upstream reach $\left(V_{i, u s}\right)$ and wood recruited along the reach by lateral input $\left(V_{i, L}\right)$, minus the volume of wood deposited within the reach during the flood $\left(V_{d, L}\right)$. Volume of large wood input laterally during a flood can come from either the river corridor $\left(V_{i, L F}\right)$ via erosion of forested alluvial surfaces such as banks and floodplains and thus associated with channel widening, or from hillslopes $\left(V_{i, L S}\right)$ as a result of landslides and debris flows. 
Although it remains challenging to parameterize each of the terms in these equations for particular segments of river corridors, the equations provide a starting point to conceptualize and quantify the relative importance of different variables through space and time. Processes such as lateral wood recruitment to the channel via bank erosion, lateral transport from the channel to the floodplain, or autochthonous recruitment within the river corridor are likely to become progressively more important moving downstream along a river, for example, whereas recruitment via mass mortality and fluvial transport downstream may dominate during severe storms (Lucía et al. 2015, Comiti et al. 2016, Steeb et al. 2016).

\section{Supplemental Text 2. Case studies of the effects of loss and restoration of large wood in river corridors}

\section{Effects of loss of large wood}

Channel morphology in the Pacific Northwest region, USA: Wood loads in managed rivers of the Puget Lowland region are one to two orders of magnitude less than before European settlement or in unmanaged rivers. Very large wood pieces that can serve as key pieces in logjams and facilitate retention of other wood pieces are particularly rare. Lack of large wood pieces and lower wood abundance have resulted in fewer and smaller pools and replacement of a dynamic, anastomosing river pattern with multiple floodplain channels and abundant edge habitat by a single channel and a floodplain that lacks sloughs. Managed rivers have lower abundance and diversity of channel and floodplain habitat and biota (Collins et al. 2002, 2012).

Salmonid habitat in western USA: Removal of LW from channels has reduced the volume of associated backwater and scour pools. LW provides overhead cover and suitable foraging positions for salmonids and pools create overwinter habitat and refuge from swift currents that can displace fish during high flows and floods. Adding wood structures in mountain streams with relatively stable channels has been demonstrated to increase trout biomass by about 50\% (Gowan and Fausch 1996) and this increase was sustained for more than two decades (White et al. 2011). Streams in old growth forests with high spatial densities of log jams have salmonid density and biomass that is 5-10 times higher than those in streams draining younger forests with low log jam densities (Herdrich et al. 2018).

Habitat diversity and invertebrate production in sand-bed rivers, southeastern USA: Removal of wood from sand-bed channels has significantly reduced hydraulic roughness (by an average of 35\% during high flows and $400 \%$ during base flows). Physical habitat diversity, as measured by flow depth, velocity, and bed material size, correlates strongly with wood load, and has also declined (Shields and Smith 1992). Wood also provides stable substrate in these channels and invertebrate production from wood surfaces constituted $73 \%$ of total main-channel production in at least one study of an unmanaged river (Benke and Wallace 2015), with far greater values of production than those from managed rivers.

Sediment dynamics in sand-bed channels of southeastern Australia: Comparison of a managed and an unmanaged river indicates that the channel from which large wood was removed and along which riparian vegetation was altered has incised (360\% increase in channel depth), steepened ( $240 \%$ increase 
in channel slope), widened (700\% increase in channel capacity), and become more laterally unstable (up to a 150 -fold increase in rate of lateral channel migration). The channel has also changed from a sediment storage area to become a sediment source to downstream regions (Brooks et al. 2003, Lester and Boulton 2008).

\section{Effects of restoration of large wood}

Engineered logjams in Washington, USA: An engineered logjam (EU) is a human-designed and constructed log structure that emulates the functions of historic, naturally-occurring logjams in order to restore riverine hydraulic, sediment, geomorphic, and ecological processes. ELs installed along the $5^{\text {th }}$ order Cispus River in 1999 were designed to protect a major highway after traditional methods of bank protection such as riprap were unsuccessful. A series of discrete ELJs spaced along the edge of the highway road fill effectively deflected flow away from the road. The ELJs were log cribs backfilled with alluvium, topped with soil, and planted with native trees (Abbe et al. 1997). In addition to protecting the road, the ELJs have created deep pools with complex overhead cover and good fish habitat. The ELJs have remained stable and promoted establishment of a riparian buffer between the edge of the road and the channel. In another project, pile-stabilized ELJs installed in 2004 to protect a road along the $4^{\text {th }}$ order Hoh River successfully restored a single-thread channel to its historic anabranching planform. This increased channel morphologic and habitat spatial heterogeneity and significantly reduced shear stress along the river's edge at the road fill (Abbe and Brooks 2011).

\section{Supplemental Text 3. Alternative river states mediated by large wood}

Ecologists use the phrase alternative state to describe a situation in which an ecosystem can exist in multiple, distinct, and self-reinforcing states in equilibrium under equivalent environmental conditions (Holling 1973; May 1977). The interpretation is that a disturbance or threshold in ecosystem response to ongoing changing conditions drives an ecosystem into an alternative state. The ecosystem then follows a different pathway of recovery, or displays hysteresis, in response to disturbances, which eventually leads to reorganization of ecosystem structure that becomes self-sustaining over time. Alternative states can exist without thresholds, however, and do not necessarily display hysteresis (Petraitis, 2013).

In the context of large wood in river corridors, alternative states of river process and form result from the presence of abundant stored wood and the absence of stored wood. Wood recruitment varies through time under natural conditions because of episodic processes such as hillslope mass movements, blowdowns, and wildfires. However, because wood decays over periods of decades to centuries in temperate and boreal latitudes, at least some wood remains in the channel and floodplain even during periods with minimal recruitment (e.g., during the period after a wildfire when all standing dead trees have fallen and trees germinating after the fire have not yet reached sufficient size to qualify as large wood when they fall over). As long as some large wood is present, the stable pieces are more likely to 
trap and retain mobile pieces entering the river corridor. Consequently, although wood load within the reach fluctuates through time, some stored wood remains present and the river corridor can be described as wood-rich (Wohl and Beckman 2014). In contrast, if management actions such as deforestation, channelization, or snagging (removal of downed wood) remove all stored large wood and reduce the potential for mobile wood to be retained within the reach in future, then the river may assume a wood-poor condition that persists for decades, even after forests have regrown and wood recruitment to the river corridor has increased (Wohl and Beckman 2014).

The presence of stored wood in a wood-rich river corridor creates secondary effects, including: a multichannel planform and greater channel lateral mobility; greater pool volume and particulate organic matter storage per unit length of valley floor; higher biomass and biodiversity; greater spatial heterogeneity of floodplain geomorphology and forests; and greater floodplain organic carbon stock in the form of soil organic carbon and downed wood (Wohl 2011; Collins et al. 2012; Herdrich et al. 2018; Livers et al. 2018; Venarsky et al. 2018). This state of river process and form can persist for centuries to millennia (e.g., Triska 1984). In the absence of stable large wood, channel planform is more likely to be single-thread and channel lateral mobility declines. Lateral connectivity between the channel and floodplain is reduced; the channel retains less organic matter; and biomass and biodiversity decline. Historical evidence indicates that this state of river process and form can result from human alterations and can persist for at least decades (Collins et al. 2002; Livers et al. 2018).

\section{Supplemental Text 4. Techniques for evaluating wood stability, mobility, and fluxes, and benefits versus hazards}

There are two components involved in evaluating wood already stored in the river corridor: stability versus mobility and the associated socioeconomic and ecological benefits versus hazards. A force-balance approach can be used to evaluate the potential stability of individual wood pieces, as described in Wohl et al. (2016). Accumulations of multiple pieces in the form of jams are commonly too complex to be adequately described using a force-balance approach, but Scott and Wohl (in prep.) present a Wood jam Dynamics Database and Assessment Model (WooDDAM) for the study and management of wood jams and jam stability. In each of these approaches, the characteristics of the wood (primarily size and shape), the position of the wood (channel margin, channel-spanning, floodplain, etc.), the flow regime (depth and duration of flow at the location of the wood, frequency of inundation), and the potential for natural stabilization by the trunks of living trees, large boulders that protrude above the bed, other wood pieces that are stable, etc, are all of primary importance. If large wood pieces or jams are likely to become mobile and create hazards, the wood can be removed, modified, or fixed in place, or wood retention structures can be installed downstream. Although large wood in channels has received the most attention, large wood on forested floodplains can be more stable where the spatial density of living trees limits transport distances of mobile wood.

Wohl et al. (2016) proposed a procedure for evaluating the environmental benefits and hazards associated with large wood in river corridors. Of particular importance here is that the balance between benefits and hazards varies between individual wood pieces or accumulations and locations within a river corridor and river network. Where benefits outweigh hazards, retention or reintroduction of wood can be used to enhance desired functions of river corridors. Wohl and Scott (in press) presented a jam stability analysis that can be used to evaluate the likelihood of jam failure or partial mobilization.

Wood fluxes have been quantitatively estimated using time-lapse photography or videography of selected points along a river (MacVicar et al. 2009, Kramer and Wohl 2014, MacVicar and Piégay 2012, Kramer et al. 2017) and from volumes of wood collected in reservoirs (Seo and Nakamura 2009, Senter et al. 2017, Nakamura et al. 2017). Results from physical experiments (Eaton et al. 2012), 
conceptual and statistical models (Czarnomski et al. 2008, Marcus et al. 2011), and numerical models (Mazzorana et al., 2011, 2018, Eaton and Hassan 2013, Ruiz-Villanueva et al. 2014) have also been used to quantitatively predict wood fluxes based on factors such as discharge magnitude and duration, as well as potential wood volumes that can be recruited and transported. Recent approaches have applied geographic information systems (Mazzorana et al. 2009, Rigon et al. 2012) and have applied fuzzy-logic principles (Ruiz-Villanueva et al. 2014) to quantify potential wood volume in a spatially distributed manner.

\section{References}

Abbe TB, Brooks AP. 2011. Geomorphic, engineering, and ecological considerations when using wood in river restoration. In, Simon A, Bennett SJ, Castro, JM, eds, Stream Restoration in Dynamic Fluvial Systems: Scientific Approaches, Analyses, and Tools. Geophysical Monograph Series 194. Washington, D.C., pp 419-451. American Geophysical Union.

Abbe TB, Montgomery DR, Petroff C. 1997. Design of stable in-channel wood debris structures for bank protection and habitat restoration: An example from the Cowlitz River, WA. In, Wang SSY, Langendoen EJ, Shields FD, eds, Proceedings of the Conference on Management of Landscapes Disturbed by Channel Incision, pp 809-816. University of Mississippi, Oxford, MS.

Benda LE, Sias JC. 2003. A quantitative framework for evaluating the mass balance of in-stream organic debris. Forest Ecology and Management 172: 1-16.

Benke AC, Wallace JB. 2015. High secondary production in a coastal plain river is dominated by snag invertebrates and fueled mainly amorphous detritus. Freshwater Biology 60: 236-255.

Braudrick CA, Grant GE, Ishikawa Y, Ikeda H. 1997. Dynamics of wood transport in streams: a flume experiment. Earth Surface Processes and Landforms 22: 669-683.

Brooks AP, Brierley GJ, Millar RG. 2003. The long-term control of vegetation and woody debris on channel and flood-plain evolution: insights from a paired catchment study in southeastern Australia. Geomorphology 51: 7-29.

Collins BD, Montgomery DR, Haas AD. 2002. Historical changes in the distribution and functions of large wood in Puget Lowland rivers. Canadian Journal of Fisheries and Aquatic Sciences 59: 66-76.

Collins BD, Montgomery DR, Fetherson KL, Abbe TB. 2012. The floodplain large wood cycle hypothesis: a mechanism for the physical and biotic structuring of temperate forested alluvial valleys in the North Pacific coastal ecoregion. Geomorphology 139-140: 460-470.

Comiti F, Lucía A, Rickenmann D. 2016. Large wood recruitment and transport during large floods : a review. Geomorphology 269: 23-39.

Czarnomski NM, Dreher DM, Snyder KU, Jones JA, Swanson FJ. 2008. Dynamics of wood in stream networks of the western Cascades Range, Oregon. Canadian Journal of Forest Research 38: 2236-2248.

Eaton BC, Hassan MA, Davidson SL. 2012. Modeling wood dynamics, jam formation, and sediment storage in a gravel-bed stream. Journal of Geophysical Research: Earth Surface 117: F00A05. doi:10.1029/2012JF002385 
Eaton BC, Hassan MA. 2013. Scale-dependent interactions between wood and channel dynamics: modeling jam formation and sediment storage in gravel-bed streams. Journal of Geophysical Research Earth Surface 118: 2500-2508.

Gowan C, Fausch KD. 1996. Long-term demographic responses of trout populations to habitat manipulation in six Colorado streams. Ecological Applications 6: 931-946.

Herdrich AT, Winkleman DL, Venarsky MP, Walters DM, Wohl E. 2018. The loss of large wood affects Rocky Mountain trout populations. Ecology of Freshwater Fish 27: 1023-1036.

Holling CS. 1973. Resilience and stability of ecological systems. Annual Review of Ecology, Evolution, and Systematics 4: 1-23.

Kramer N, Wohl E. 2014. Estimating fluvial wood discharge using time-lapse photography with varying sampling intervals. Earth Surface Processes and Landforms 39: 844-852.

Kramer N, Wohl E, Hess-Homeier B, Leisz S. 2017. The pulse of driftwood export from a very large forested river basin over multiple time scales, Slave River, Canada. Water Resources Research 53: 19281947.

Lancaster ST, Hayes SK, Grant GE. 2001. Modeling sediment and wood storage and dynamics in small mountainous watersheds. In: Dorava JM, Montgomery DR, Palcsak BB, Fitzpatrick FA. (Eds.), Geomorphic Processes and Riverine Habitat. American Geophysical Union Press, Washington, DC, pp. 85-102.

Lester RE, Boulton AJ. 2008. Rehabilitating agricultural streams in Australia with wood: a review. Environmental Management 42: 310-326.

Livers B, Wohl E, Jackson KJ, Sutfin NA. 2018. Historical land use as a driver of alternative states for stream form and function in forested mountain watersheds of the Southern Rocky Mountains. Earth Surface Processes and Landforms 43: 669-684.

Lucía A, Comiti F, Borga M, Cavalli M, Marchi L. 2015. Dynamics of large wood during a flash flood in two mountain catchments. Natural Hazards Earth Syst. Sci. Discuss. 3: 1643-1680.

MacVicar B, Piegay H, Henderson A, Comiti F, Oberlin C, Pecorari E. 2009. Quantifying the temporal dynamics of wood in large rivers: field trials of wood surveying, dating, tracking, and monitoring techniques. Earth Surface Processes and Landforms 34: 2031-2046.

MacVicar B, Piegay H. 2012. Implementation and validation of video monitoring for wood budgeting in a wandering piedmont river, the Ain River (France). Earth Surface Processes and Landforms 37: 12721289.

Marcus WA, Rasmussen J, Fonstad MA. 2011. Response of the fluvial wood system to fire and floods in northern Yellowstone. Annals of the Association of American Geographers 101: 21-44.

May RM. 1977. Thresholds and breakpoints in ecosystems with a multiplicity of stable states. Nature 269: 471-477.

Mazzorana B, Zischg A, Largiader A, Hubl J. 2009. Hazard index maps for woody material recruitment and transport in alpine catchments. Natural Hazards and Earth System Science 9: 197-209. 
Mazzorana B, Ruiz-Villanueva V, Marchi L, Cavalli M, Gems B, Gschnitzer T, Mao L, Iroumé A, Valdebenito G. 2018. Assessing and mitigating large wood-related hazards in mountain streams: recent approaches. Journal of Flood Risk Management 11: 207-222.

Nakamura F, Seo JI, Akasaka T, Swanson FJ. 2017. Large wood, sediment, and flow regimes: their interactions and temporal changes caused by human impacts in Japan. Geomorphology 279: 176-187.

Petraitis P. 2013. Multiple Stable States in Natural Ecosystems. Oxford University Press: Oxford; 188.

Rigon E, Comiti F, Lenzi MA. 2012. Large wood storage in streams of the eastern Italian Alps and the relevance of hillslope processes. Water Resources Research 48:

https://doi.org/10.1029/2010WR009854

Ruiz-Villanueva V, Blade E, Sanchez-Juny M, Marti-Cardona B, Diez-Herrero A, Bodoque JM. 2014. Twodimensional numerical modeling of wood transport. Journal of Hydroinformatics 16: 1077-1096.

Scott DN, Wohl E. in prep. Wood jam dynamics database and assessment model (WooDDAM): A monitoring protocol for an evolving, public database and predictive model. In revision after submission to Water Resources Research.

Senter AE, Pasternack GB, Piégay H, Vaughan MC, Lehyan JS. 2017. Wood export varies among decadal, annual, seasonal, and daily scale hydrologic regimes in a large, Mediterranean climate, mountain river watershed. Geomorphology 276: 164-179.

Seo JI, Nakamura F. 2009. Scale-dependent controls upon the fluvial export of large wood from river catchments. Earth Surface Processes and Landforms 34: 786-800.

Shields FD, Smith RH. 1992. Effects of large woody debris removal on physical characteristics of a sandbed river. Aquatic Conservation: Marine and Freshwater Fisheries 2: 145-163.

Steeb N, Rickenmann D, Badoux A, Rickli C, Waldner P. 2016. Large wood recruitment processes and transported volumes in Swiss mountain streams during the extreme flood of August 2005. Geomorphology 279: 112-127.

Triska FJ. 1984. Role of wood debris in modifying channel geomorphology and riparian areas of a large lowland river under pristine conditions: a historical case study. Verhandlungen Internationale Verein Limnologie 22: 1876-1892.

Venarsky MP, Walters DM, Hall RO, Livers B, Wohl E. 2018. Shifting stream planform state decreases stream productivity yet increases riparian animal production. Oecologia 187: 167-180.

White SL, Gowan C, Fausch KD, Harris JG, Saunders WC. 2011. Response of trout populations in five Colorado streams two decades after habitat manipulation. Canadian Journal of Fisheries and Aquatic Sciences 68: 2057-2063.

Wohl E. 2011. Threshold-induced complex behavior of wood in mountain streams. Geology 39: 587-590.

Wohl E. 2017. Bridging the gaps: an overview of wood across time and space in diverse rivers. Geomorphology 279: 3-26. 
Wohl E, Beckman ND. 2014. Leaky rivers: implications of the loss of longitudinal fluvial disconnectivity in headwater streams. Geomorphology 205: 27 -35.

Wohl E, Bledsoe BP, Fausch KD, Kramer N, Bestgen KR, Gooseff MN. 2016. Management of large wood in streams: an overview and proposed framework for hazard evaluation. Journal of the American Water Resources Association 52: 315-335.

Wohl E, Cadol D, Pfeiffer A, Jackson K, Laurel D. 2018a. Distribution of large wood within river corridors in relation to flow regime in the semiarid western US. Water Resources Research 54: 1890-1904. Wohl E, Scott DN, Lininger KB. 2018b. Spatial distribution of channel and floodplain large wood in forested river corridors of the Northern Rockies. Water Resources Research.

298 Wohl E, Scott DN. in press. Managing for Large Wood and Beaver Dams in Stream Corridors. USDA 


\begin{tabular}{|c|c|}
\hline Stationary wood & References \\
\hline \multicolumn{2}{|l|}{ Water flux } \\
\hline $\begin{array}{l}\text { Attenuates downstream flux by } \\
\text { - ponding water upstream from obstacles (large jams in small channels) } \\
\text { - enhancing overbank flow across floodplain } \\
\text { - promoting formation of multiple, subparallel channels } \\
\text { - enhancing hyporheic exchange flows }\end{array}$ & $\begin{array}{l}\text { Richmond \& Fausch 1995, Montgomery et al. } \\
\text { 1995, Gurnell \& Sweet 1998, He et al. } 2009 \\
\text { Sear et al. } 2010 \\
\text { Wohl 2011, Collins et al. } 2012 \\
\text { Hester \& Doyle 2008, Sawyer et al. } 2012\end{array}$ \\
\hline \multicolumn{2}{|l|}{ Sediment flux } \\
\hline $\begin{array}{l}\text { Attenuates downstream flux by } \\
\text { - increasing hydraulic roughness \& reducing sediment transport capacity } \\
\text { - creating backwaters \& flow separation \& associated sediment storage } \\
\text { - enhancing overbank flow } \& \text { deposition on floodplain } \\
\text { - directing current toward bed } \& \text { banks \& enhancing local scour } \\
\text { - increasing patchiness of bed substrate }\end{array}$ & $\begin{array}{l}\text { Brooks et al. 2003, Wilcox et al. } 2011 \\
\text { Elosegi et al. 2016a,b, Wohl \& Scott } 2017 \\
\text { Sear et al. } 2010 \\
\text { Cherry \& Beschta } 1989 \\
\text { Buffington \& Montgomery } 1999\end{array}$ \\
\hline \multicolumn{2}{|l|}{ Water quality } \\
\hline er temperature and chem & \\
\hline
\end{tabular}




\begin{tabular}{|c|c|}
\hline $\begin{array}{l}\text { - } \text { promoting hyporheic exchange flows } \\
\text { - } \text { retaining particulate organic matter } \\
\text { - promoting nutrient uptake }\end{array}$ & $\begin{array}{l}\text { Sawyer et al. } 2012 \\
\text { Bilby \& Likens 1980, Beckman \& Wohl } 2014 \\
\text { Warren et al. } 2013\end{array}$ \\
\hline \multicolumn{2}{|l|}{ Cross-sectional geometry \& bedforms } \\
\hline $\begin{array}{l}\text { Alters channel form by } \\
\text { - } \text { altering bedform type or dimensions } \\
\text { - promoting alluvial rather than bedrock substrate }\end{array}$ & $\begin{array}{l}\text { MacFarlane \& Wohl } 2003 \\
\text { Montgomery et al. 1996, Pollock et al. } 2014\end{array}$ \\
\hline \multicolumn{2}{|l|}{ Channel planform } \\
\hline $\begin{array}{l}\text { Alters channel planform by } \\
\text { - promoting avulsion \& multithread channels } \\
\text { - enhancing bar \& island formation } \\
\text { - blocking entrance to secondary channels or cutoff meanders }\end{array}$ & $\begin{array}{l}\text { Wohl 2011, Collins et al. } 2012 \\
\text { Fetherston et al. 1995, Gurnell et al. 2001, } \\
\text { 2005, Nakamura et al. } 2012 \\
\text { Hickin } 1984\end{array}$ \\
\hline \multicolumn{2}{|l|}{ Floodplain } \\
\hline $\begin{array}{l}\text { Buried wood } \\
\text { - creates erosionally resistant patches } \\
\text { Wood on floodplain surface } \\
\text { - enhances soil moisture \& nutrient content } \\
\text { Influences forest regeneration }\end{array}$ & $\begin{array}{l}\text { Collins et al. } 2012 \\
\text { Zalamea et al. } 2007\end{array}$ \\
\hline
\end{tabular}


- deflects current \& enhances bank scour and channel avulsion that remove living trees

- provides germination sites for seedlings

Collins et al. 2012

Enhances spatial heterogeneity of floodplain geomorphology \& vegetation

Osei et al. 2015

Montgomery \& Abbe 2006

Habitat

Wood in channel and on floodplain creates habitat

- for microbial communities, plants, amphibians, reptiles, birds and small animals when exposed

- for macroinvertebrates \& fish when inundated

Harmon et al. 1986, Schowalter et al. 1998

Benke \& Wallace 1990, 2015, Fausch \&

Northcote 1992, Warren et al. 2013, Pilotto et

al. 2016, Harvey et al. 2017

Mobile wood

References

- enhances local bed \& bank erosion

- batters riparian vegetation \& alters wood recruitment

- maintains wood flux to lake and marine environments

Cherry \& Beschta 1989

Johnson et al. 2000

Simenstad et al. 2003, Marburg et al. 2006 


\section{References}

Beckman ND, Wohl E. 2014. Carbon storage in mountainous headwater streams: the role of old-growth forest and logjams. Water Resources Research 50: 2376-2393.

Benke AC, Wallace JB. 1990. Wood dynamics in coastal plain backwater streams. Canadian Journal of Fisheries and Aquatic Sciences 47: 92-99.

Benke AC, Wallace JB. 2015. High secondary production in a coastal plain river is dominated by snag invertebrates and fueled mainly amorphous detritus. Freshwater Biology 60: 236-255.

Bilby RE Likens GE. 1980. Importance of organic debris dams in the structure and function of stream ecosystems. Ecology 61: 1107-1113.

Brooks AP, Brierley GJ, Millar RG. 2003. The long-term control of vegetation and woody debris on channel and flood-plain evolution: insights from a paired catchment study in southeastern Australia. Geomorphology 51: 7-29.

Buffington JD, Montgomery DR. 1999. Effects of hydraulic roughness on surface textures of gravel-bed rivers. Water Resources Research 35: 3507-3521.

Cherry J, Beschta RL. 1989. Coarse woody debris and channel morphology: a flume study. Water Resources Bulletin 25: 1031-1036.

Collins BD, Montgomery DR, Fetherson KL, Abbe TB. 2012. The floodplain large wood cycle hypothesis: a mechanism for the physical and biotic structuring of temperate forested alluvial valleys in the North Pacific coastal ecoregion. Geomorphology 139-140: 460-470.

Benke AC, Wallace JB. 1990. Wood dynamics in coastal plain backwater streams. Canadian Journal of Fisheries and Aquatic Sciences 47: 92-99.

Benke AC, Wallace JB. 2015. High secondary production in a coastal plain river is dominated by snag invertebrates and fueled mainly amorphous detritus. Freshwater Biology 60: 236-255.

Elosegi A, Díez JR, Flores L, Molinero J. 2016a. Pools, channel form, and sediment storage in wood-restored streams: Potential effects on downstream reservoirs. Geomorphology 279: 111.

Elosegi A, Elorriaga C, Flores L, Martí E, Díez J. 2016b. Restoration of wood loading has mixed effects on water, nutrient, and leaf retention in Basque mountain streams. Freshwater Science 35: 41-54.

Fausch KD, Northcote TG. 1992. Large woody debris and salmonid habitat in a small coastal British Columbia stream. Canadian Journal of Fisheries and Aquatic Sciences 49: 682-693. 
Fetherston KL, Naiman RJ, Bilby RE. 1995. Large woody debris, physical process, and riparian forest development in montane river networks of the Pacific Northwest. Geomorphology 13: 133-144.

Gurnell AM, Sweet R. 1998. The distribution of large woody debris accumulations and pools in relation to woodland stream management in a small, low-gradient stream. Earth Surface Processes and Landforms 23: 1101-1121.

Gurnell AM, Petts GE, Hannah DM, Smith DPG, Edwards PJ, Kollmann J, Ward JV, Tockner K. 2001. Riparian vegetation and island formation along the gravel-bed Fiume Tagliamento, Italy. Earth Surface Processes and Landforms 26: 31-62.

Gurnell A, Tockner K, Edwards P, Petts G. 2005. Effects of deposited wood on biocomplexity of river corridors. Ecological Society of America 3: 377-382.

Harmon ME, Franklin JF, Swanson FJ, Sollins P, Gregory SV, Lattin JD, Anderson NH, Cline SP, Aumen NG, Sedell JR, Lienkaemper GW, Cromack K, Cummins JW. 1986. Ecology of coarse woody debris in temperate ecosystems. Advances in Ecological Research 15: 133-302.

Harvey GL, Henshaw AJ, Parker C, Sayer CD. 2017. Re-introduction of structurally complex wood jams promotes channel and habitat recovery from overwidening: Implications for river conservation. Aquatic Conservation: Marine and Freshwater Ecosystems: 1-13.

He Z, Wu W, Shields FDJ. 2009. Numerical analysis of effects of large wood structures on channel morphology and fish habitat suitability in a Southern US sandy creek. Ecohydrology 2: 370-380.

Hester ET, Doyle MW. 2008. In-stream geomorphic structures as drivers of hyporheic exchange. Water Resources Research 44. Doi: 10.1029/2006WR005810.

Hickin EJ. 1984. Vegetation and river channel dynamics. Canadian Geographer 28: 111-126.

Johnson SL, Swanson FJ, Grant GE, Wondzell SM. 2000. Riparian forest disturbances by a mountain flood - the influence of floated wood. Hydrological Processes 14: 3031-3050.

MacFarlane WA, Wohl E. 2003. Influence of step composition on step geometry and flow resistance in step-pool streams of the Washington Cascades. Water Resources Research 39: http://dx.doi.org/10.1029/2001WR001238.

Marburg AE, Turner MG, Kratz TK. 2006. Natural and anthropogenic variation in coarse wood among and within lakes. Journal of Ecology 94: 558-568.

Montgomery DR, Abbe TB. 2006. Influence of logjam-formed hard points on the formation of valley-bottom landforms in an old-growth forest valley, Queets River, Washington, USA. Quaternary Research 65: 147-155. 
Montgomery DR, Buffington JM, Smith RD, Schmidt KM, Pess G. 1995. Pool spacing in forest channels. Water Resources Research 31: 1097-1105.

Montgomery DR, Abbe TB, Peterson NP, Buffington JM, Schmidt KM, Stock JD. 1996. Distribution of bedrock and alluvial channels in forested mountain drainage basins. Nature 381 : 587-589.

Nakamura F, Fuke N, Kubo M. 2012. Contributions of large wood to the initial establishment and diversity of riparian vegetation in a bar-braided temperate river. Plant Ecology 213: 735747

Osei NA, Gurnell AM, Harvey GL. 2015. The role of large wood in retaining fine sediment, organic matter and plant propagules in a small, single-thread forest river. Geomorphology 235: 77-87.

Pilotto F, Harvey GL, Wharton G, Pusch MT. 2016. Simple large wood structures promote hydromorphological heterogeneity and benthic macroinvertebrate diversity in low-gradient rivers. Aquatice Science 78: 755-766.

Pollock MM, Beechie TJ, Wheaton JM, Jordan CE, Bouwes N, Weber N, Volk C. 2014. Using beaver dams to restore incised stream ecosystems. Bioscience 64: 279-290.

Richmond AD, Fausch KD. 1995. Characteristics and function of large woody debris in subalpine Rocky Mountain streams in northern Colorado. Canadian Journal of Fisheries and Aquatic Sciences 52: 1789-1802.

Sawyer AH, Cardenas MB, Buttles J. 2012. Hyporheic temperature dynamics and heat exchange near channel-spanning logs. Water Resources Research 48: W01529. http://dx.doi.org/10.1029/2011WR011200.

Schowalter TD, Zhang YL, Sabin TE. 1998. Decomposition and nutrient dynamics of oak (Quercus spp.) logs after five years of decomposition. Ecography 21: 3-10.

Sear DA, Millington CE, Kitts DR, Jeffries R. 2010. Logjam controls on channel: floodplain interactions in wooded catchments and their role in the formation of multichannel patterns. Geomorphology 116: 305-319.

Simenstad CA, Wick A, Van De Wetering S, Bottom DL. 2003. Dynamics and ecological functions of wood in estuarine and coastal marine ecosystems. In: Gregory SV, Boyer KL, Gurnell AM. (Eds.), The Ecology and Management of Wood in World Rivers. American Fisheries Society Symposium 37, pp. 265-277 Bethesda, MD.

Warren DR, Judd KE, Bade DL, Likens GE, Kraft CE. 2013. Effects of wood removal on stream habitat and nitrate uptake in two northeastern US headwater streams. Hydrobiologia 717: 119131. 
402 Wilcox AC, Wohl EE, Comiti F, Mao L. 2011. Hydraulics, morphology, and energy dissipation in 403 an alpine step-pool channel. Water Resources Research 47: W07514.

404 http://dx.doi.org/10.1029/2010WR010192.

405 Wohl E. 2011. Threshold-induced complex behavior of wood in mountain streams. Geology 39:

406 587-590.

407 Wohl E, Scott DN. 2017. Wood and sediment storage and dynamics in river corridors. Earth 408 Surface Processes and Landforms 42: 5-23.

409 Zalamea M, Gonzalez G, Ping CL, Michaelson G. 2007. Soil organic matter dynamics under 410 decaying wood in a subtropical wet forest: effect of tree species and decay stage. Plant and Soil 411 296: 173-185. 
